\title{
EVALUATION OF NONPOINT-SOURCE CONTAMINATION, WISCONSIN: FOR WATER YEAR 1995
}

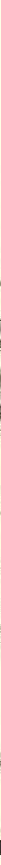

Prepared in cooperation with the WISCONSIN DEPARTMENTOF NATURALRESOURCES

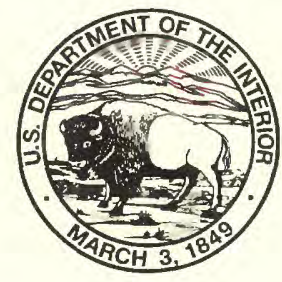




\section{EVALUATION OF NONPOINT-SOURCE CONTAMINATION, WISCONSIN: SELECTED TOPICS FOR WATER YEAR 1995}

By D.W. Owens, S.R. Corsi, and K.F. Rappold

U.S. GEOLOGICAL SURVEY

Open-File Report 96-661A

Prepared in cooperation with the

WISCONSIN DEPARTMENT OF NATURAL RESOURCES

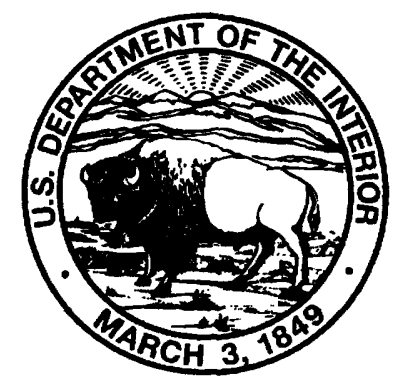

Madison, Wisconsin 


\title{
U.S. DEPARTMENT OF THE INTERIOR BRUCE BABBITT, Secretary
}

\author{
U.S. GEOLOGICAL SURVEY \\ Gordon P. Eaton, Director
}

District Chief

U.S. Geological Survey

6417 Normandy Lane

Madison, WI 53719
U.S. Geological Survey

Branch of Information Services

Box 25286

Denver, CO 80225-0286 


\section{CONTENTS}

Abstract

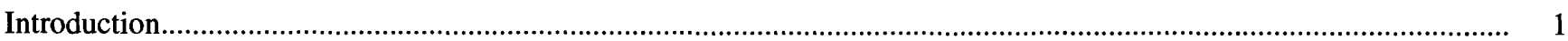

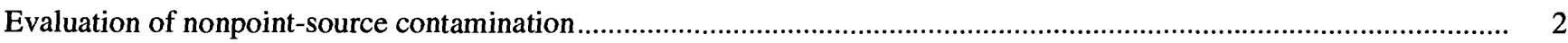

Land-use and best management practices inventory .......................................................................................... 3

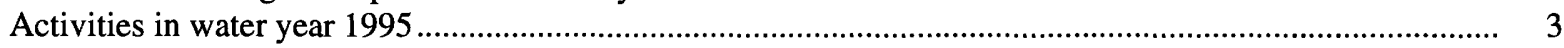

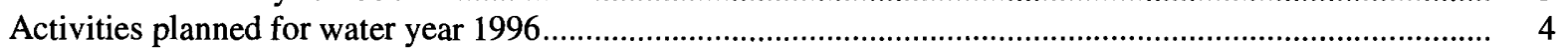

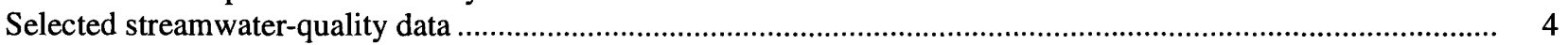

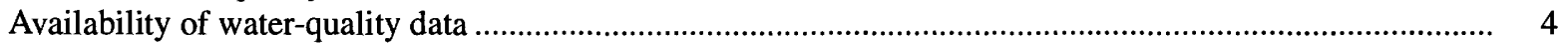

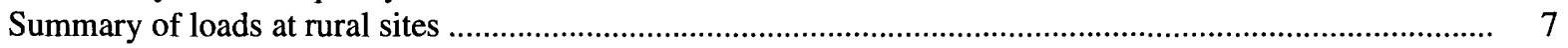

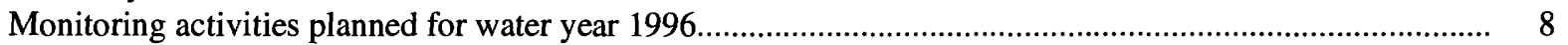

Quality assurance and quality control....................................................................................................... 8

Blank samples for inorganic constituents at rurai sites ........................................................................... 8

Polycyclic aromatic hydrocarbon sampling at urban sites .................................................................. 9

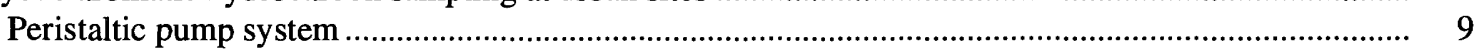

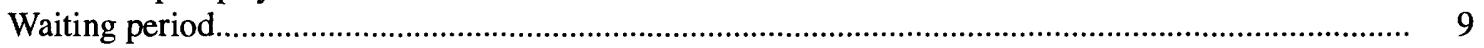

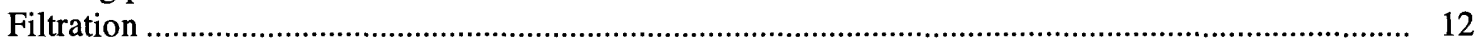

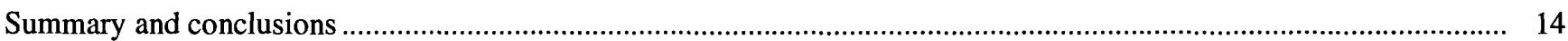

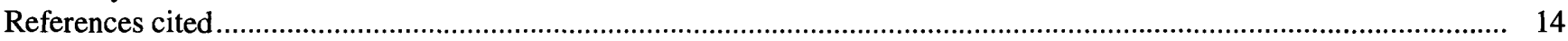

Appendix 1. Storm-load data for rural watershed-management evaluation monitoring sites, Wisconsin, water years 1985-93.....

Appendix 2. Storm-load data for urban watershed-management evaluation monitoring sites, Wisconsin, water years 1991-94.

Appendix 2.1.Uncertainty in urban storm-load data

\section{FIGURES}

1. Map showing locations of rural and urban sites in the Wisconsin watershed-management evaluation monitoring program, water year 1995

2-5. Graphs showing:

2. Number of storms through water year 1995 for which loads were calculated at the Wisconsin evaluation monitoring sites before implementation of best-management practices (BMP's) and during transitional periods

3. Comparison of grab samples and peristaltic-pump samples for polycyclic aromatic hydrocarbon compounds detected in each of three sets of urban stormwater samples, Madison, Wisconsin.

4. Comparison of average concentrations for capped samples and samples left open for 24 hours for polycyclic aromatic hydrocarbon compounds detected in urban stormwater samples, Madison, Wisconsin........

5. Comparison of polycyclic aromatic hydrocarbon samples filtered one time and two times.

\section{TABLES}

1. Characteristics of sites in the Wisconsin evaluation monitoring program

2. Summary of eligible, contracted, and implemented rural best-management practices in nonpoint-source evaluation monitoring watersheds, Wisconsin

3. Milestone dates for project selection, watershed assessment, plan approval, signup period, end of BMP funding, pre-BMP period, transitional period, and post-BMP period for nonpoint-source evaluation monitoring watersheds, Wisconsin....

4. Summary of annual and snowmelt-period suspended-sediment or suspended-solids loads, total-phosphorus loads, and streamflow at Wisconsin rural evaluation monitoring sites, water years $1985-86$ and $1990-94$.

5. Number of splitter-blank and field-blank samples with concentrations greater than the limit of quantification and number of splitter-blank and field samples collected, Wisconsin evaluation monitoring program, water years 1994-95. 


\title{
CONVERSION FACTORS AND ABBREVIATED WATER-QUALITY UNITS
}

\begin{tabular}{rll}
\hline Multiply & By & To Obtain \\
\hline inch (in.) & & \\
foot (ft) & 25.4 & millimeter \\
acre & 0.3048 & meter \\
hectare \\
square mile $\left(\mathrm{mi}^{2}\right)$ & 0.4048 & square kilometer \\
million cubic feet $\left(\mathrm{Mft}^{3}\right)$ & 2.590 & million cubic meters \\
pound $(\mathrm{lb})$ & 0.02832 & gram \\
pounds per square mile (lb/mi $\left.{ }^{2}\right)$ & 453.6 & kilograms per square kilometer $\left(\mathrm{kg} / \mathrm{km}^{2}\right)$ \\
ton (short) & 0.17573 & megagram (mg) \\
\hline
\end{tabular}

\begin{abstract}
Abbreviated water-quality units used in this report: Chemical concentrations and water temperature are given in metric units. Chemical concentration is given in milligrams per liter $(\mathrm{mg} / \mathrm{L})$ or micrograms per liter $(\mu \mathrm{g} / \mathrm{L})$. Milligrams per liter is a unit expressing the concentration of chemical constituents in solution as weight (milligrams) of solute per unit volume (liter) of water. One thousand micrograms per liter is equivalent to one milligram per liter. For concentrations less than $7,000 \mathrm{mg} / \mathrm{L}$, the numerical value is the same as for concentrations in parts per million. Other units of measurement used in this report are microsiemens per centimeter at $25^{\circ} \mathrm{Celsius}(\mu \mathrm{S} / \mathrm{cm})$, micrometers $(\mu \mathrm{m})$, and bacteria colonies per 100 milliliters of water sample (col. $/ 100 \mathrm{~mL})$.
\end{abstract}




\title{
EVALUATION OF NONPOINT-SOURCE CONTAMINATION, WISCONSIN: SELECTED TOPICS FOR WATER YEAR 1995
}

\author{
By D.W. Owens, S.R. Corsi, and K.F. Rappold
}

\section{Abstract}

The objective of the watershed-management evaluation monitoring program in Wisconsin is to evaluate the effectiveness of best-management practices (BMP's) for controlling nonpointsource contamination in eight rural and four urban watersheds. This report, the fourth in an annual series of reports, presents a summary of the data collected for the program by the U.S. Geological Survey and the results of several detailed analyses of the data.

To complement assessments of water quality, a land-use and BMP inventory is ongoing for 12 evaluation monitoring projects to track nonpoint sources of contamination in each watershed and to document implementation of BMP's that were designed to cause changes in the water quality of streams. Each year, updated information is gathered, mapped, and stored in a geographicinformation-system data base. Summaries of landuse, BMP implementation, and water-quality data collected during water years 1989-95 are presented.

Storm loads, snowmelt-period loads, and annual loads of suspended sediment and total phosphorus are summarized for eight rural sites. Storm-load data for suspended solids, total phosphorus, total recoverable lead, copper, zinc, and cadmium are summarized for four urban sites.

Quality-assurance and quality-control (QA) QC) samples were collected at the eight rural sites to evaluate inorganic sample contamination and at one urban site to evaluate sample-collection and filtration techniques for polycyclic aromatic hydrocarbons (PAH's). Some suspended solids and fecal coliform contamination was detected at the rural sites. Corrective actions will be taken to address this contamination. Evaluation of PAH sample-collection techniques did not uncover any deficiencies, but the small amount of data collected was not sufficient to draw any definite conclusions. Evaluation of PAH filtration techniques indicate that water-sample filtration with $0.7-\mu \mathrm{m}$ glass-fiber filters in an aluminum filter unit does not result in significant loss of PAH.

\section{INTRODUCTION}

In October 1989, the U.S. Geological Survey (USGS) began a watershed-management evaluation monitoring program in cooperation with the Wisconsin Department of Natural Resources (WDNR). The overall objective of the 12 individual projects in the program (4 in urban areas and 8 in rural areas) is to determine whether the quality of water in a receiving stream has improved as a result of the implementation of land-management practices in the watershed. This determination is made through monitoring of water chemistry and ancillary variables before best-management practices (BMP's) are implemented, during BMP implementation, and after BMP's have been completely implemented. In this report, the period before BMP implementation is termed "pre-BMP," the period during active implementation is termed "transitional," and the period after complete implementation is termed "post-BMP."

The county Land Conservation Departments (LCD's) and the WDNR have identified nonpoint sources of contamination in the eight rural watersheds. This information was used to select sites that are eligible for partial funding of BMP implementation. The LCD's are in the process of contacting landowners to request that they implement the appropriate BMP's for streamwater-quality improvement. This BMP implementation is voluntary and, therefore, may result in varied success, depending largely on the amount of land treated, and also on the effectiveness of implemented BMP's in improving water quality. 


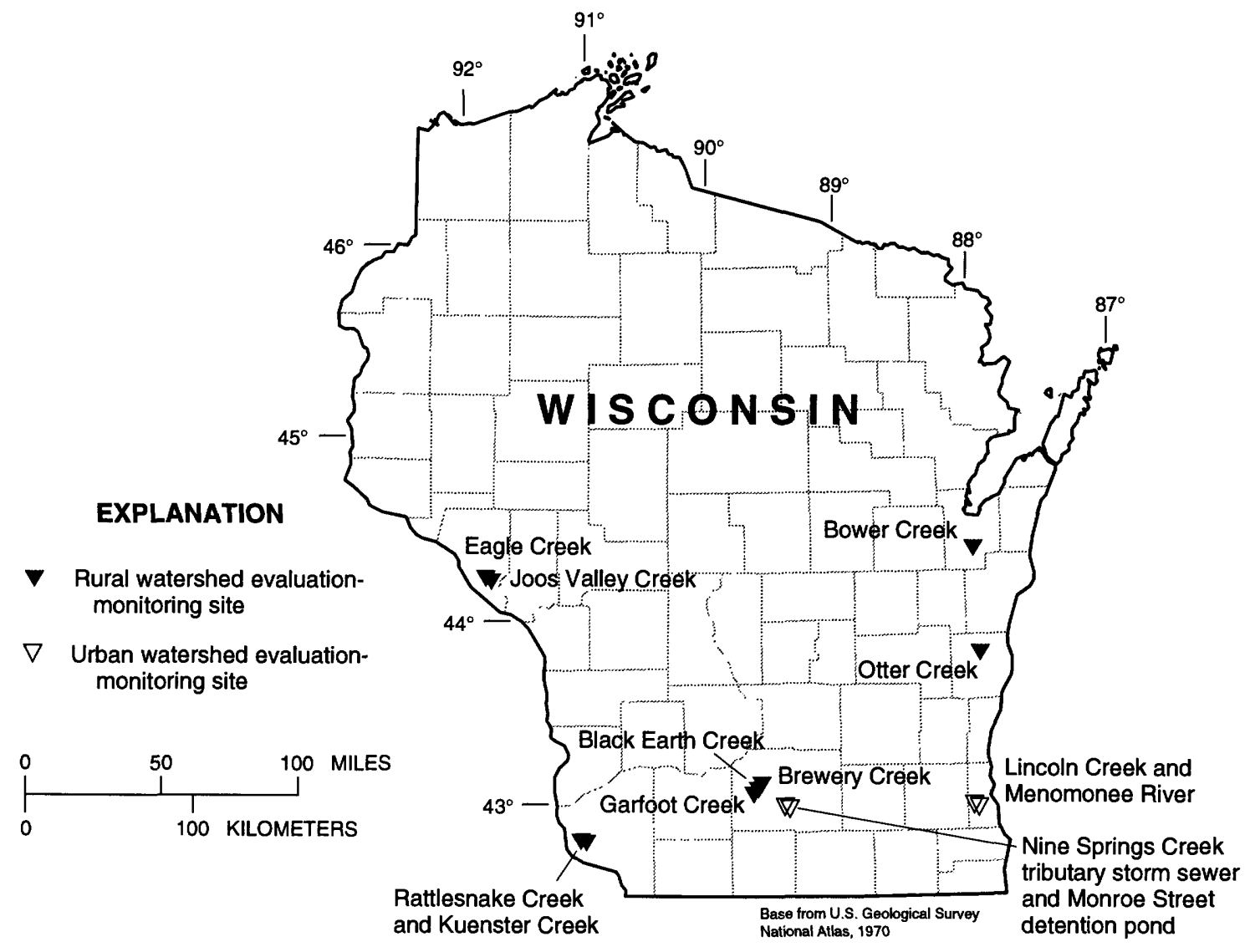

Figure 1. Locations of rural and urban sites in the Wisconsin watershed-management evaluation monitoring program, water year 1995.

The WDNR and each city have identified nonpoint sources of contamination for the four urban watersheds. Goals for reduction of nonpoint-source contamination have been set, but specific plans identifying the types and locations of BMP's needed to achieve these goals have not been defined.

Among the criteria for site selection were likelihood for extensive BMP implementation, relatively small watershed size (less than $50 \mathrm{mi}^{2}$ ), and feasibility of accurate measurement of streamflow in the watershed. An additional stream, a reach of Black Earth Creek, was selected for a detailed analysis of dissolved oxygen. Locations of the sites are shown in figure 1, and a brief summary of site characteristics is given in table 1.

\section{EVALUATION OF NONPOINT-SOURCE CONTAMINATION}

This report, the fourth in a series of annual progress reports (Graczyk and others, 1993; Corsi and others, 1994; Walker and others, 1995), is divided into three sections. The following topics are addressed: (1) land-use and best-management-practices inventory, including a discussion of data-collection efforts and the status of BMP implementation, (2) streamwater-quality data, including a discussion of rural annual snowmelt and rainfall loads, and (3) quality assurance and quality control practices, including an analysis of rural blank samples collected to examine for contamination of samples by inorganic constituents and an analysis of sampling and filtration methods for polycyclic aromatic hydrocarbons (PAH's) in urban areas. For sec- 
Table 1. Characteristics of sites in the Wisconsin evaluation monitoring program [Data-collection period in water years; $\mathrm{mi}^{2}$, square miles]

\begin{tabular}{|c|c|c|c|c|c|}
\hline Site name & $\begin{array}{c}\text { U.S. Geological } \\
\text { Survey station } \\
\text { number }\end{array}$ & $\begin{array}{l}\text { Data } \\
\text { collection } \\
\text { period }\end{array}$ & $\begin{array}{l}\text { Surface-water } \\
\text { divide } \\
\text { contributing } \\
\text { drainage area } \\
\left(\mathrm{mi}^{2}\right)\end{array}$ & Site type & Data collected \\
\hline $\begin{array}{l}\text { Black Earth Creek at } \\
\text { County Trunk P }\end{array}$ & 05406460 & $\begin{array}{l}\text { 1985-86; } \\
1990-95\end{array}$ & 12.8 & Rural & $\begin{array}{l}\text { Dissolved oxygen and } \\
\text { water temperature }\end{array}$ \\
\hline $\begin{array}{l}\text { Black Earth Creek at } \\
\text { Mills Street }\end{array}$ & 05406476 & $\begin{array}{l}\text { 1985-86; } \\
1990-95\end{array}$ & 22.7 & Rural & $\begin{array}{l}\text { Dissolved oxygen and } \\
\text { water temperature }\end{array}$ \\
\hline $\begin{array}{l}\text { Black Earth Creek at } \\
\text { South Valley Road }\end{array}$ & 05406497 & $\begin{array}{l}1985-86 \\
1990-95\end{array}$ & 37.8 & Rural & $\begin{array}{l}\text { Dissolved oxygen and } \\
\text { water temperature }\end{array}$ \\
\hline Bower Creek & 04085119 & $1991-95$ & 14.8 & Rural & Water chemistry ${ }^{1}$ \\
\hline Brewery Creek & 05406470 & $\begin{array}{l}1985-86 \\
1990-95\end{array}$ & 7.7 & Rural & Water chemistry ${ }^{2}$ \\
\hline Eagle Creek & 05378185 & $1990-95$ & 14.3 & Rural & Water chemistry ${ }^{1}$ \\
\hline Garfoot Creek & 05406491 & $\begin{array}{l}1985-86 \\
1990-95\end{array}$ & 5.39 & Rural & $\begin{array}{l}\text { Water chemistry }{ }^{2} \text { and } \\
\text { dissolved oxygen }\end{array}$ \\
\hline Joos Valley Creek & 05378183 & $1990-95$ & 5.89 & Rural & Water chemistry ${ }^{1}$ \\
\hline Kuenster Creek & 054134435 & $1993-95$ & 9.59 & Rural & $\begin{array}{l}\text { Water chemistry }{ }^{1} \text { and } \\
\text { dissolved oxygen }\end{array}$ \\
\hline Lincoln Creek & 040869415 & $1993-95$ & 9.56 & Urban & Water chemistry ${ }^{1}$ \\
\hline Menomonee River & 04087120 & $1991-95$ & 123 & Urban & Water chemistry $^{1}$ \\
\hline $\begin{array}{l}\text { Monroe Street detention } \\
\text { pond inlet }\end{array}$ & 430309089260701 & $1991-95$ & .372 & Urban & Water chemistry $^{1}$ \\
\hline $\begin{array}{l}\text { Nine Springs Creek } \\
\text { tributary storm sewer }\end{array}$ & 05429268 & $1991-95$ & .18 & Urban & Water chemistry ${ }^{1}$ \\
\hline Otter Creek & 040857005 & $1991-95$ & 9.5 & Rural & $\begin{array}{l}\text { Water chemistry }{ }^{1} \text { and } \\
\text { dissolved oxygen }\end{array}$ \\
\hline Rattlesnake Creek & 05413449 & $1992-95$ & 42.4 & Rural & $\begin{array}{l}\text { Water chemistry }{ }^{1} \text { and } \\
\text { dissolved oxygen }\end{array}$ \\
\hline
\end{tabular}

${ }^{1}$ Samples analyzed for suspended solids, total phosphorus, and ammonia nitrogen.

${ }^{2}$ Samples analyzed for suspended sediment, total phosphorus, and ammonia nitrogen.

tions describing ongoing data-collection efforts, data collected during water year 1995 are summarized and, if appropriate, implications for future data-collection efforts are discussed. (A water year is the period beginning October 1 and ending September 30; the water year is designated by the calendar year in which it ends.) Storm-load data summarized in appendixes 1 and 2 include data collected through water year 1994 for rural sites and water year 1995 for urban sites.

\section{Land-Use and Best-Management- Practices Inventory}

The land-use inventory program began in 1992 to provide information on the effects of land-use and land-treatment changes on water quality. A brief description of the program is given in Corsi and others (1994), and a comprehensive summary of the program is given in Wierl and others (1996). This section summarizes activities for water year 1995 and planned activities for water year 1996.

\section{Activities in Water Year 1995}

The land-use-inventory program has been tracking BMP implementation and changes in land use and land cover with a geographic information system (GIS) since 1992. A detailed description of the program is given in Wierl and others (1996). The GIS data base developed by the USGS in cooperation with the 
WDNR is managed with $\mathrm{ARC} / \mathrm{INFO}^{1}$ software. GIS data layers were produced from 1:24,000-scale topographic maps and aerial photographs at an approximate scale of 1:600. These GIS layers include surface water drainage-basin boundaries, hydrography, hydrologic units, elevation, roads, stream and rain gages, BMP's, forests, and field boundaries. The GIS data base has been used to (1) track the implementation of BMP's;

(2) display annual land cover or changes in land use;

(3) depict the areas that are critical nonpoint sources of contaminants; (4) provide inputs for water-quality models; and (5) perform various queries and analyses.

A water-quality model (WINHUSLE ${ }^{2}$ ) has been used to estimate the quantity of sediment and phosphorus reaching Otter Creek from each field. Inputs for the model were imported from three GIS layers: field boundaries, elevation, and hydrologic units. The model results will be used to assess the need for specific BMP's within the Otter Creek watershed.

Updates on contracted or implemented BMP's were obtained from the local LCD's and from the WDNR, Water Resources Bureau. This information was entered into the GIS layer for BMP's. Ephemeral gullies were inventoried in spring 1995. The length, vertical depth, average width and the length of time it took for the gully to develop were used to estimate the sediment loading from a particular gully. Field inventories were conducted in summer and fall 1995 to identify the agricultural crops that were grown. This crop information was entered into the GIS layer for field boundaries.

Nonpoint sources of contamination have been identified and quantified for most of the monitored watersheds. These sources include runoff from barnyards and erosion from streambanks, uplands and gullies. Nonpoint-contaminant-source data were obtained from the priority watershed plans, local LCD's, pollutant loadings estimated from water-quality models, and completed watershed inventories (for example, gully and streambank erosion inventories).

Eligible, contracted, and installed BMP's for the evaluation monitoring watersheds are summarized in table 2. The GIS layers for BMP implementation are updated twice a year if BMP's are either contracted or

\footnotetext{
${ }^{1}$ Use of trade names in the report is for identification purposes only and does not constitute endorsement by the U.S. Geological Survey.

${ }^{2}$ WINHUSLE is an empirical water-quality model that estimates the sediment yield from each field to the receiving water, and the in-stream sediment deposition rate (Wisconsin Department of Natural Resources, 1994).
}

implemented. Two of the rural evaluation monitoring watersheds will complete their BMP funding periods for implementing BMP's by the end of 1997 (table 3), four of the rural watersheds will complete their BMP funding periods by the end of 1999 , and the remaining two rural watersheds will complete their BMP funding periods by the end of 2000 .

\section{Activities Planned for Water Year 1996}

The following land-use and BMP monitoring activities are planned for water year 1996:

1. Update all pertinent land-use data in the GIS data base. The data base will provide the information necessary to create GIS maps.

2. Publish a USGS Open-File report that includes descriptions of the evaluation monitoring watersheds.

3. Complete an inventory of agricultural crops being grown in each watershed.

4. Complete an inventory of BMP's implemented in each watershed.

5. Complete an inventory of ephemeral gully erosion in each watershed.

6. Complete water-quality model runs for some of the remaining monitored watersheds.

\section{Selected Streamwater-Quality Data}

Streamwater-quality data are summarized in two parts. The first part discusses the availability of waterquality data, including loads for stormflow periods. The second part discusses specific data compiled at rural sites, and includes (1) a graph of the number of storms and estimated constituent loads, (2) annual constituent loads for the specific period of record at each site, and (3) a breakdown of annual rural loads into snowmelt and stormflow sources of runoff.

\section{Availability of Water-Quality Data}

Precipitation, streamflow volume, and storm loads for several water-quality constituents have been computed for all monitored storm periods and summarized for rural sites (appendix 1) and urban sites (appendix 2). The rural data are summarized through water year 1994. Data collection was suspended in 


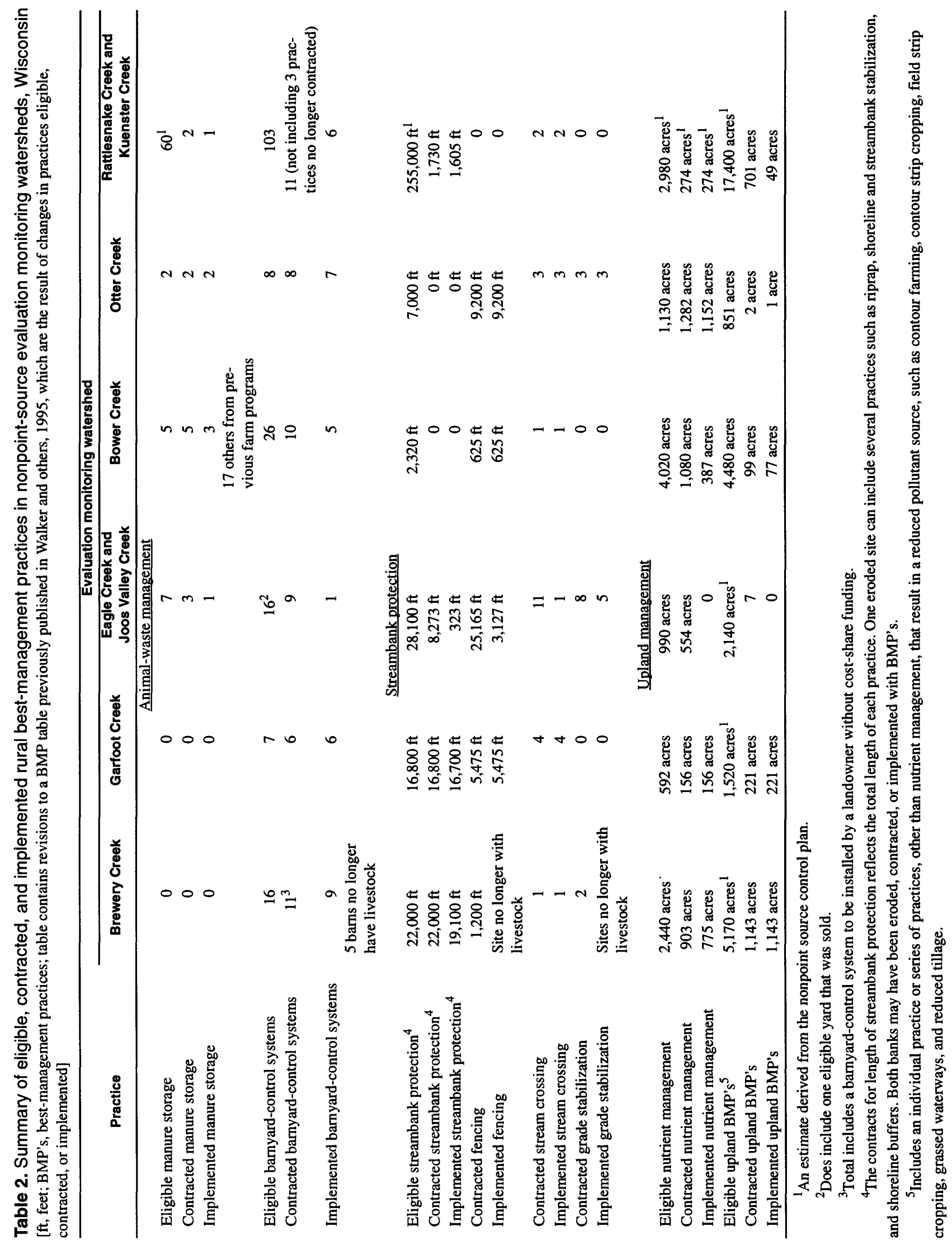




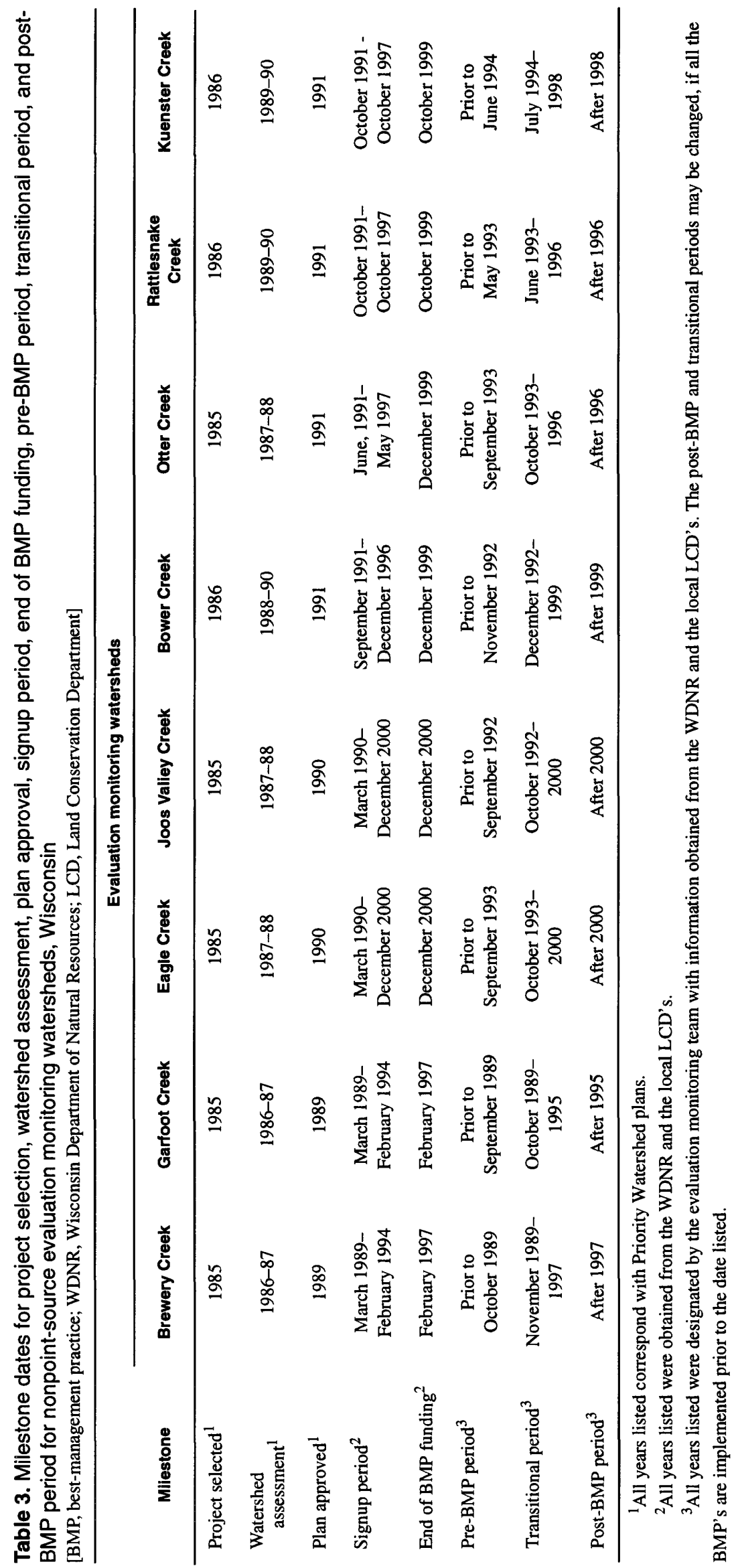




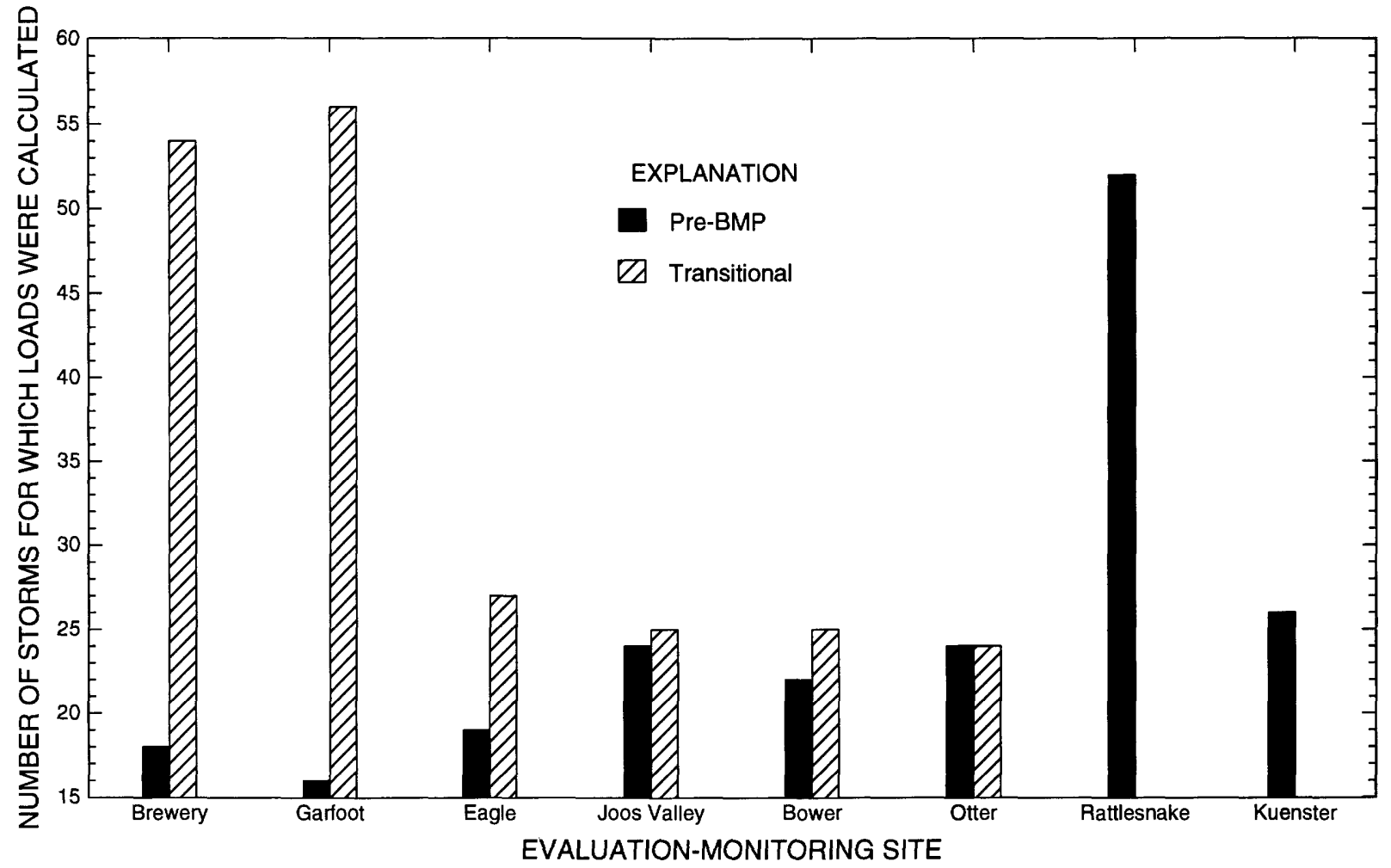

Figure 2. Number of storms through water year 1995 for which loads were calculated at the Wisconsin evaluation monitoring sites before implementation of best-management practices (BMP's) and during transitional periods.

1994 for three of the urban sites and in 1995 for the remaining urban site pending approved watershed plans. Accordingly, data in appendix 2 are through the end of the appropriate data-collection period. Daily loads for selected constituents and discrete concentration data for the samples used to calculate these loads are published in the USGS annual water-data reports for Wisconsin (Holmstrom and others, 1986-87; Holmstrom and Erickson, 1989; Holmstrom and others, 1990-95). Maximum, minimum, and mean dissolved-oxygen concentrations and water temperatures also are published in these annual reports. Data for water year 1995 are published in the annual report for 1995. Constituent loads for stormflow periods for water year 1995 are to be published in the 1996 annual progress report on the evaluation monitoring program. Data are available by request from the USGS office in Madison, Wis.

\section{Summary of Loads at Rural Sites}

Water-quality monitoring at the eight rural evaluation monitoring sites (fig. 1) continued in water year 1995 with sampling during base-flow and stormflow periods. Instantaneous water-quality data were used in conjunction with continuous streamflow data to estimate total constituent loads for stormflow periods. Suspended-sediment or suspended-solids, totalphosphorus, and ammonia-nitrogen loads were computed at the eight rural evaluation monitoring sites. For Brewery and Garfoot Creeks, suspended-sediment loads were computed to be consistent with pre-BMP data collected in a previous study; for all other sites, suspended-solids loads were computed. Ammonianitrogen loads were not computed for sites on Otter and Bower Creeks. The rural storm-load data will be used to evaluate the effect of BMP's on streamwater quality. Previous research using the rural regression analysis (Walker and Graczyk, 1993; Walker, 1994) has shown theoretically that the minimum detectable change at rural sites becomes distinguishable at roughly 40 total storms; this corresponds to 20 pre-BMP and 20 postBMP storms for a balanced data collection. The number of pre-BMP and post-BMP storms for which loads were calculated at rural evaluation monitoring sites is shown in figure 2. Loads for a sufficient number of storms are probably available for the pre-BMP implementation period at five of the sites; at the other three 
sites, BMP implementation has begun, so collection of additional pre-BMP data is not possible.

Annual loads of suspended sediment or suspended solids and total phosphorus were determined at each of the eight rural evaluation monitoring sites (fig. 1) for the entire period of data collection. The annual loads are summarized in table 4.

A significant part of the annual rural load may be transported during snowmelt runoff periods which are frequent in Wisconsin during the winter and early spring. A determination of the percentage of annual load contributed by snowmelt-period runoff will indicate the importance of snowmelt periods for the rural regression analyses. Snowmelt periods were defined as periods when snow was either falling or already on the ground. Climatological data from the closest station collecting snow and snow-on-ground data were used for the snowmelt-period determination.

For each water year, daily mean loads were summed for snowmelt periods. These load data are summarized in table 4.

\section{Monitoring Activities Planned for Water Year 1996}

The following water-quality-monitoring activities are planned for water year 1996:

1. Continue collection of rural stormflow samples for determination of suspended-solids or suspended-sediment, total-phosphorus and ammonia-nitrogen loads. Data collection may be scaled back at some sites if implementation of BMP's in the watersheds has not begun. Intensive data collection can begin again once a sufficient number of BMP's have been implemented.

2. Continue dissolved-oxygen monitoring at the four sites (Kuenster, Rattlesnake and Garfoot Creeks and Black Earth Creek at South Valley Road). Analyze data for the coldwater sites where most of the BMP's have been installed. Available data may be sufficient at the end of water year 1996 to determine whether dissolved-oxygen concentrations have changed as a result of the BMP implementation.

\section{Quality Assurance and Quality Control}

In this section, two components of quality-assurance/quality-control (QA/QC) for evaluation monitoring sites are summarized and evaluated. First, rural field-blank and splitter-blank samples collected in water years 1994-95 are considered; second, some components of the urban sampling protocol for polycyclic aromatic hydrocarbons (PAH's) are investigated.

\section{Blank Samples for Inorganic Constituents at Rural Sites}

One part of the QA/QC plan for rural evaluation monitoring sites includes regular collection of blank samples from the automatic samplers and the sample splitter. Runoff samples are collected by use of an automatic refrigerated sampler. Plastic sample tubing connects the stream to a peristaltic pump, which pumps water into one of twenty-four 1-L plastic bottles that are stored in the refrigerator until retrieved by field personnel. The samples are then capped and transported to a field office, where they are split by use of a 10-port, plastic, small-volume sample splitter and sent to the Wisconsin State Laboratory of Hygiene (WSLH) for analysis. Field-blank samples are collected by attaching one end of a short section of tubing onto the stream end of the plastic sample tubing and placing the other end in a bottle of Milli-Q water. Milli-Q water is then pumped through the automatic sampler into a 1-L plastic bottle in the refrigerator. The bottle is capped and transported to a field office, where its contents are split and sent to the WSLH for analysis. Splitter-blank samples are collected by pouring Milli-Q water through the sample splitter and sending the resulting sample to the WSLH for analysis. A more detailed description of blank- sample collection is given in Graczyk and others (1993).

The field- and splitter-blank samples for rural evaluation monitoring sites were analyzed for biochemical oxygen demand (BOD), total phosphorus (TP), ammonia nitrogen $\left(\mathrm{NH}_{3}-\mathrm{N}\right)$, suspended solids (SS), and fecal coliform bacteria. Four splitter-blank samples were collected and analyzed for BOD, seven for $\mathrm{TP}, \mathrm{NH}_{3}-\mathrm{N}$, and $\mathrm{SS}$, and eight for fecal coliform. One sample each of BOD, TP, NH3-N, and SS had concentrations slightly above the limit of quantification (LOQ) (table 5). All fecal coliform concentrations were below the LOQ. 
A total of 71 field-blank samples were collected during water years 1994 and 1995. Concentrations were above the LOQ in at least 19 samples for all constituents. For all constituents except $\mathrm{NH}_{3}-\mathrm{N}$ concentrations were measurable in more than 50 percent of the samples (table 5).

There appears to be some source of BOD, TP, $\mathrm{NH}_{3}-\mathrm{N}$, and SS contamination in the field blanks. Because concentrations of BOD and TP in the fieldblank samples are all relatively low compared to those in most runoff samples collected by the automatic samplers, contamination by these constituents is not a serious concern. Concentrations of SS and fecal coliform in field-blank samples were generally low compared to those in most rural runoff samples. In a few field-blank samples, however, SS and fecal coliform concentrations were greater than those in some runoff samples. In 14 of 67 field-blank samples, suspended solids concentrations were greater than $20 \mathrm{mg} / \mathrm{L}$; and in 12 of 55 fecal coliform samples concentrations were greater than $500(\mathrm{col}$.)/100 mL. Both of these concentrations are considered to be low but not uncommon for rural runoff samples. This contamination is a problem that warrants further investigation and appropriate corrective action.

The source of BOD, TP, $\mathrm{NH}_{3}-\mathrm{N}$, and SS contamination in the field blanks must lie with the automaticsampling process or the bottle-handling procedure because splitter blanks have not been contaminated. Contamination is most likely due to residue particulate matter and streamwater in the sample tubing. If this is the case, the problem would probably be solved by cleaning the sample tubing with a tubing brush and rinsing the sample tubing periodically (once every 2 weeks would probably be sufficient). This possibility will be investigated during water year 1996.

\section{Polycyclic Aromatic Hydrocarbon Sampling at Urban Sites}

Some components of the current sampling and sample-processing methods for PAH's at the urban watershed-management evaluation monitoring sites were investigated in 1995. Runoff samples are collected by use of refrigerated automatic peristaltic pump samplers. Teflon-lined 3/8-in. sample tubing connects the stream or storm sewer to a peristaltic pump, which pumps water through approximately $3 \mathrm{ft}$ of polyethylene tubing into one of four $10-\mathrm{L}$ open wide-mouth glass bottles stored in the refrigerator. Field personnel visit the site within 24 hours of the end of each runoff period. Samples are then capped and transported in an iced cooler to the USGS office in Madison at a temperature of approximately $4^{\circ} \mathrm{C}$. The samples are split by use of a Teflon-lined churn splitter and filtered by use of a $0.7-\mu \mathrm{m}$ glass fiber filter. Three components of this procedure were investigated: (1) the peristaltic pump system, (2) the waiting period from when the samples are pumped into the 10-L glass bottles to when they are retrieved and capped by field personnel, and (3) the filtration system. The components were tested with urban stormwater runoff from a storm sewer that drains the West Towne Mall parking lot in Madison, Wis.

\section{Peristaltic Pump System}

To evaluate the peristaltic pump system, three sets of two samples each were collected. Each set of samples contained a grab sample from the stormwater runoff from the storm sewer and a simultaneous sample collected by placing a bottle directly under the outlet from the peristaltic pump system. Concentrations of PAH's from the peristaltic pump sample were greater than those of the grab samples for the first two sets of samples but were slightly less for the third set of samples (fig. 3). Eleven of sixteen PAH's were detected in all samples. The five PAH's not detected were acenaphthene, acenaphtylene, dibenzo[A,H]anthracene, fluorene, and naphthalene. In the first two sets of samples differences between the pump samples and the grab samples are more apparent.

\section{Waiting Period}

To evaluate the effect of the waiting period on PAH's for the time the samples are pumped into the 10 -L glass bottles to when they are retrieved and capped by field personnel, a grab sample was collected directly from the storm sewer. The Teflon-lined churn splitter was used to split this sample into three amber 1-L glass bottles filled completely (ambient samples 1 , 2 , and 3 ) and one clear 10-L glass bottle filled half full. The 1-L bottles were capped and shipped for analysis. The 10-L bottle was left uncovered and refrigerated for 24 hours to simulate a runoff event where samples may be left in the automatic sampler for as long as 24 hours before field personnel retrieve them. The sample was then split into three amber 1-L glass bottles (uncovered sample 1,2, and 3) that were capped and shipped for analysis. Ten of fifteen PAH's were detected in all samples. Non-detected target PAH compounds include 


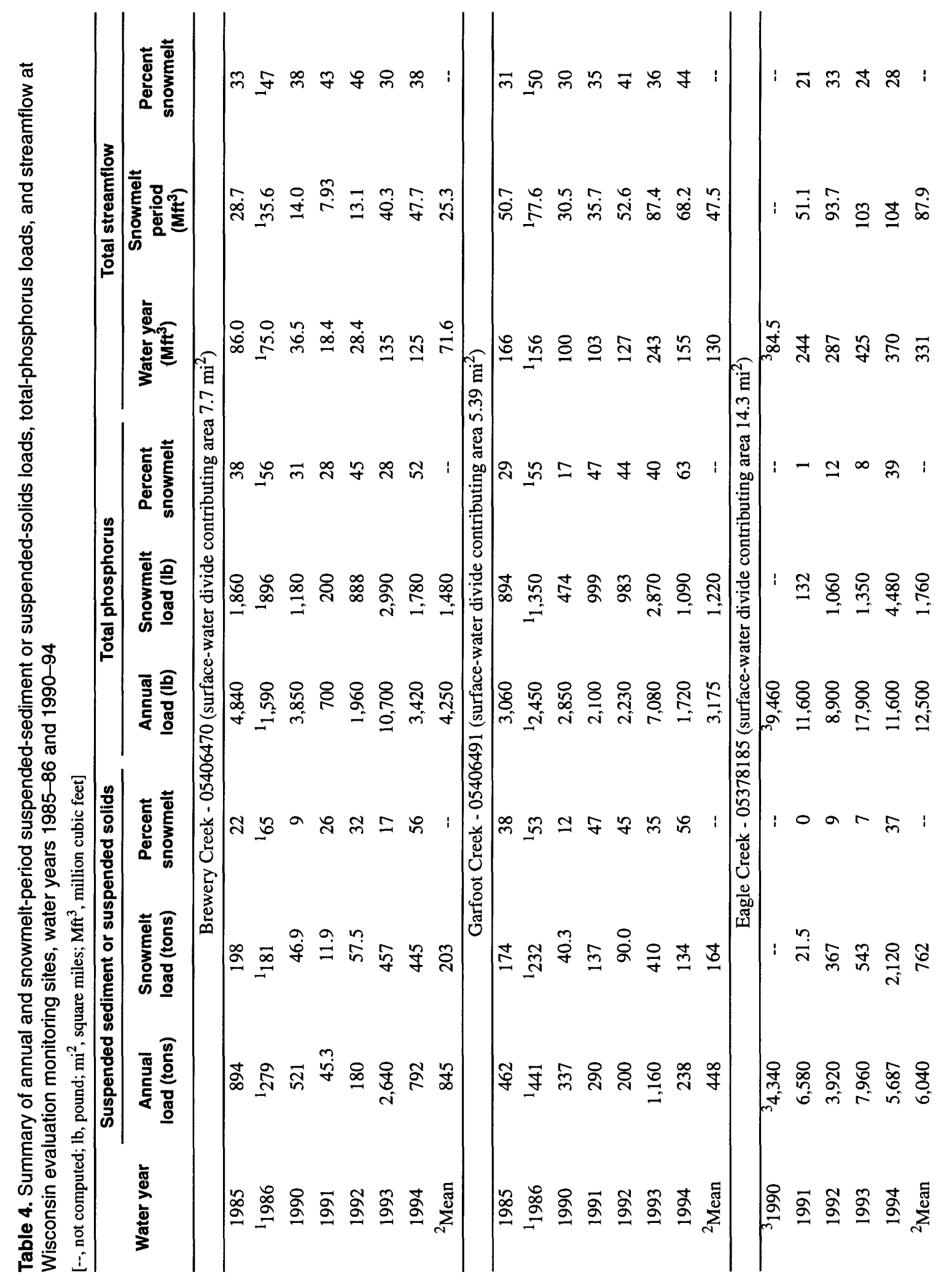




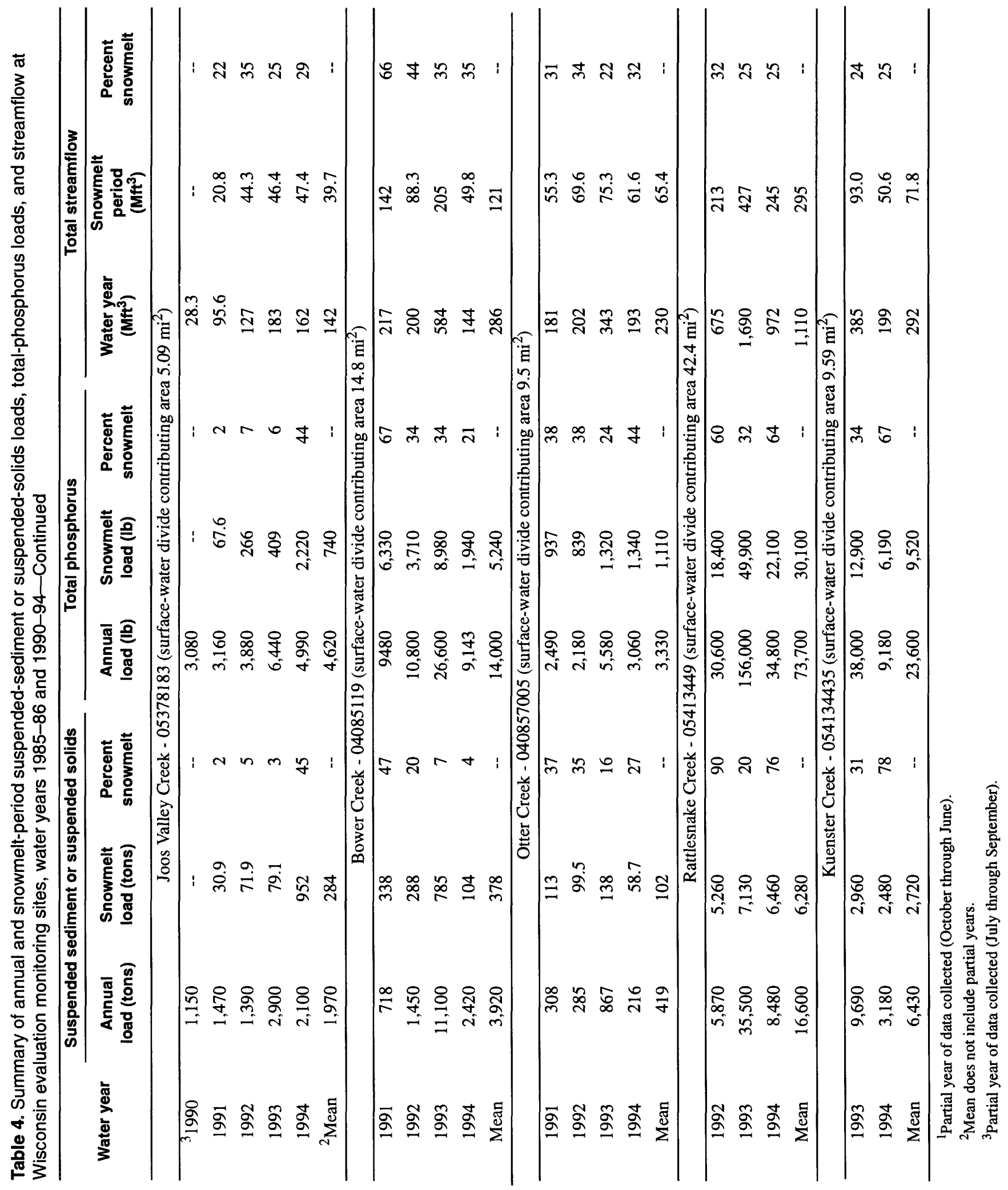


Table 5. Number of splitter-blank and field-blank samples with concentrations greater than the limit of quantification and number of splitter-blank and field-blank samples collected, Wisconsin evaluation monitoring program, water years 1994-95

$[\mathrm{a} / \mathrm{b}$, where $\mathrm{a}=$ number of blank samples with concentration exceeding the limits of quantification (LOQ), and $b=$ number of blank samples collected; $\mathrm{mg} / \mathrm{L}$, milligrams per liter; $\mathrm{mL}$, milliliter]

\begin{tabular}{|c|c|c|c|c|c|}
\hline Site name & $\begin{array}{c}\text { Biochemical } \\
\text { oxygen } \\
\text { demand }\end{array}$ & $\begin{array}{c}\text { Total } \\
\text { phosphorus } \\
(\mathrm{LOQ}=.031 \mathrm{mg} / \mathrm{L})\end{array}$ & $\begin{array}{c}\text { Ammonia } \\
\text { nitrogen } \\
(\mathrm{LOQ}=.085 \mathrm{mg} / \mathrm{L})\end{array}$ & $\begin{array}{c}\text { Suspended } \\
\text { solids } \\
(\mathrm{LOQ}=19.8 \mathrm{mg} / \mathrm{L})\end{array}$ & $\begin{array}{c}\text { Fecal coliform } \\
(\mathrm{LOQ}=10 \mathrm{col} . / 100 \mathrm{~mL})\end{array}$ \\
\hline \multicolumn{6}{|c|}{ Splitter blanks } \\
\hline Splitters & $1 / 4$ & $1 / 7$ & $1 / 7$ & $1 / 7$ & $0 / 8$ \\
\hline \multicolumn{6}{|c|}{ Field bIanks } \\
\hline Brewery Creek & $5 / 5$ & $4 / 11$ & $2 / 10$ & $7 / 10$ & $4 / 5$ \\
\hline Garfoot Creek & $7 / 7$ & $7 / 10$ & $4 / 10$ & $7 / 9$ & $5 / 6$ \\
\hline Eagle Creek & $1 / 5$ & $2 / 9$ & $4 / 9$ & $5 / 9$ & $2 / 9$ \\
\hline Joos Valley Creek & $1 / 5$ & $1 / 9$ & $2 / 9$ & $6 / 9$ & $2 / 10$ \\
\hline Bower Creek & $1 / 2$ & $0 / 2$ & $0 / 2$ & $0 / 2$ & $1 / 3$ \\
\hline Otter Creek & $6 / 7$ & $2 / 7$ & $1 / 7$ & $1 / 7$ & $2 / 7$ \\
\hline Rattlesnake Creek & $6 / 8$ & $8 / 8$ & $3 / 8$ & $7 / 8$ & $7 / 7$ \\
\hline Kuenster Creek & $5 / 5$ & $10 / 13$ & $3 / 13$ & $12 / 13$ & $7 / 8$ \\
\hline
\end{tabular}

acenaphthene, acenaphtylene, dibenzo[A,H] anthracene, fluorene, and naphthalene. Concentrations of ambient samples 1,2, and 3 were averaged and concentrations of uncovered samples 1,2 , and 3 were averaged. Concentrations of all constituents from the uncovered samples were within 12 percent of those from the ambient samples (fig. 4).

The above evaluation shows that the sampling methods for PAH's do not give results that are drastically different from grab sampling of stormwater, but the data set is too small to draw any definite conclusions. The small number of samples collected resulted in a small range of constituent concentrations and five of the target PAH's are not even detected in these samples. To fully evaluate the effect of the waiting period on the results for PAH's, samples would have to be collected at other sites and under other conditions so that all the target PAH's would be detected and a greater range of concentrations would be available for between-method comparisons.

\section{Filtration}

Water samples for PAH's for the urban evaluation monitoring sites are filtered by use of a positive displacement pump that pushes water through a $0.7-\mu \mathrm{m}$ glass-fiber filter in an aluminum filter unit, as outlined in Sandstrom (1995). This method is commonly used in the USGS for filtration prior to analysis for pesticides and other organic compounds, but it has not been explicitly evaluated for PAH's. Because PAH's are hydrophobic compounds, a primary concern about filtering water samples is the loss of PAH's due to sorption onto the sampling apparatus or the filter. To evaluate the possibility of PAH sorption, six samples were collected and processed with a double filtration procedure. The samples were filtered, and a portion of the filtrate was analyzed (filtrate 1). The remaining filtrate was filtered again and then analyzed (filtrate 2). Concentrations of PAH's should be less in the second filtrate if PAH compounds are sorbing to the sampling apparatus or filtration unit. Of 16 target PAH compounds, 3 were detected in all but 1 sample.

Results from the first filtration and the second filtration are virtually identical (fig. 5). Concentrations from the second filtrate are not consistently less than those from the first. The observed differences may be simply a result of analytical variability. Concentrations from the second filtrate were within 12 percent of concentrations from the first filtrate for all samples but three. The concentration of pyrene in the first filtrate of sample 1 was $0.05 \mu \mathrm{g} / \mathrm{L}$, whereas that in the second filtrate was less than the limit of quantification $(0.04 \mu \mathrm{g} / \mathrm{L})$; the concentration of pyrene in sample 6 is 20 percent greater than that in the first filtrate, and the concentration of fluoranthene in the second filtrate is 21 percent less than that of the first filtrate.

Results from this investigation do not indicate a problem with the PAH filtration method; however, the investigation probably would have been more conclu- 

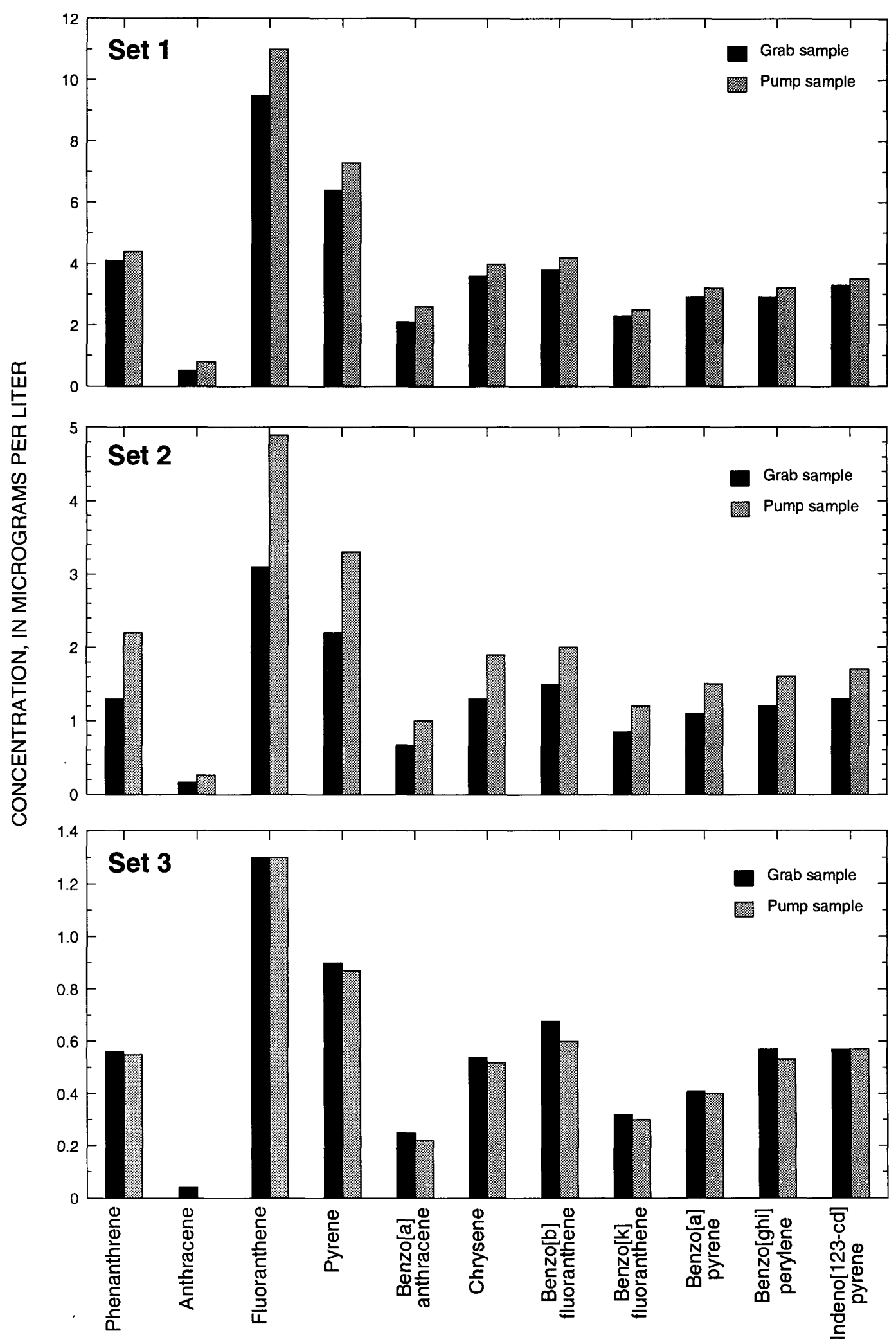

COMPOUND

Figure 3. Comparison of grab samples and peristaltic-pump samples for polycyclic aromatic hydrocarbon compounds detected in each of three sets of urban stormwater samples, Madison, Wisconsin. 


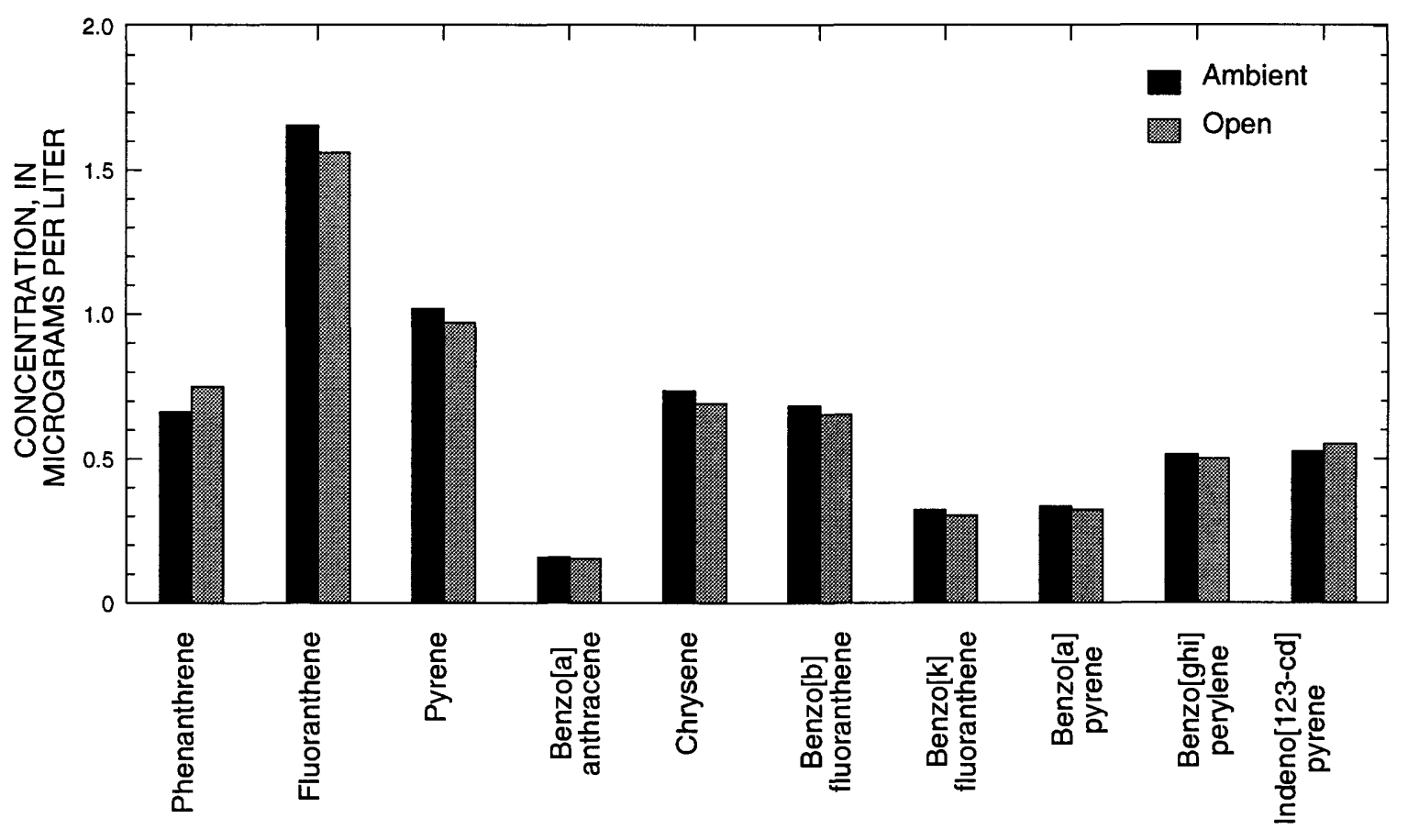

COMPOUND

Figure 4. Comparison of average concentrations for capped samples (ambient) and samples left open for 24 hours (open) for polycyclic aromatic hydrocarbon compounds detected in urban stormwater samples, Madison, Wisconsin.

sive with additional data and a greater range of concentrations.

\section{SUMMARY AND CONCLUSIONS}

This report is an annual summary of the data collected for the Wisconsin watershed-management evaluation monitoring program and a presentation of the results from several specific analyses within this program.

A land use and best-management-practice inventory is ongoing for each evaluation monitoring project to track the nonpoint sources of contamination in each watershed. Information is being gathered from the county Land Conservation Districts (Wisconsin Department of Natural Resources, Water Resources Bureau, and other sources). This information is mapped and stored in a geographic-information-system data base. Each year, the information for each watershed is reviewed and updated.

Data on precipitation, streamflow volume, and storm loads of suspended solids and total phosphorus have been compiled for the eight rural sites through water year 1994 (appendix 1). Data on precipitation, streamflow volume, and storm loads for suspended solids, total phosphorus, and total recoverable lead, copper, zinc, and cadmium have been compiled for the four urban sites through water year 1995 (appendix 2). Annual and snowmelt-period loads for suspended sed- iment and total phosphorus were estimated for the eight rural sites.

Quality-assurance and quality-control (QA/QC) samples were collected at rural sites for inorganic constituents and at urban sites for polycyclic aromatic hydrocarbons (PAH's). Blank quality-control samples were collected at eight of the rural evaluation monitoring sites. The rural sampling protocol was designed to isolate contamination from the automatic sampler and the sample splitter. Low levels of contamination were found for biochemical oxygen demand, total phosphorus, and ammonia nitrogen. Levels of suspended solids and fecal coliform contamination in the automatic sampling equipment warrant investigations and corrective action. QA/QC sampling for PAH's at urban sites was inconclusive. QA/QC completed on the PAH filtration indicates that $0.7-\mu \mathrm{m}$ glass-fiber filter in an aluminum filter unit can be used for sample filtration.

\section{REFERENCES CITED}

Box, G.E.P., Hunter W.G., and Hunter J.S., 1978, Statistics for experimenters: New York, John Wiley and Sons, $653 \mathrm{p}$.

Corsi, S.R., Walker, J.F., Graczyk, D.J., Greb, S.R., Owens, D.W., and Rappold, K.F., 1994, Evaluation of nonpointsource contamination Wisconsin-selected streamwaterquality data, land-use and best-management practices inventory, and quality assurance and quality control, 

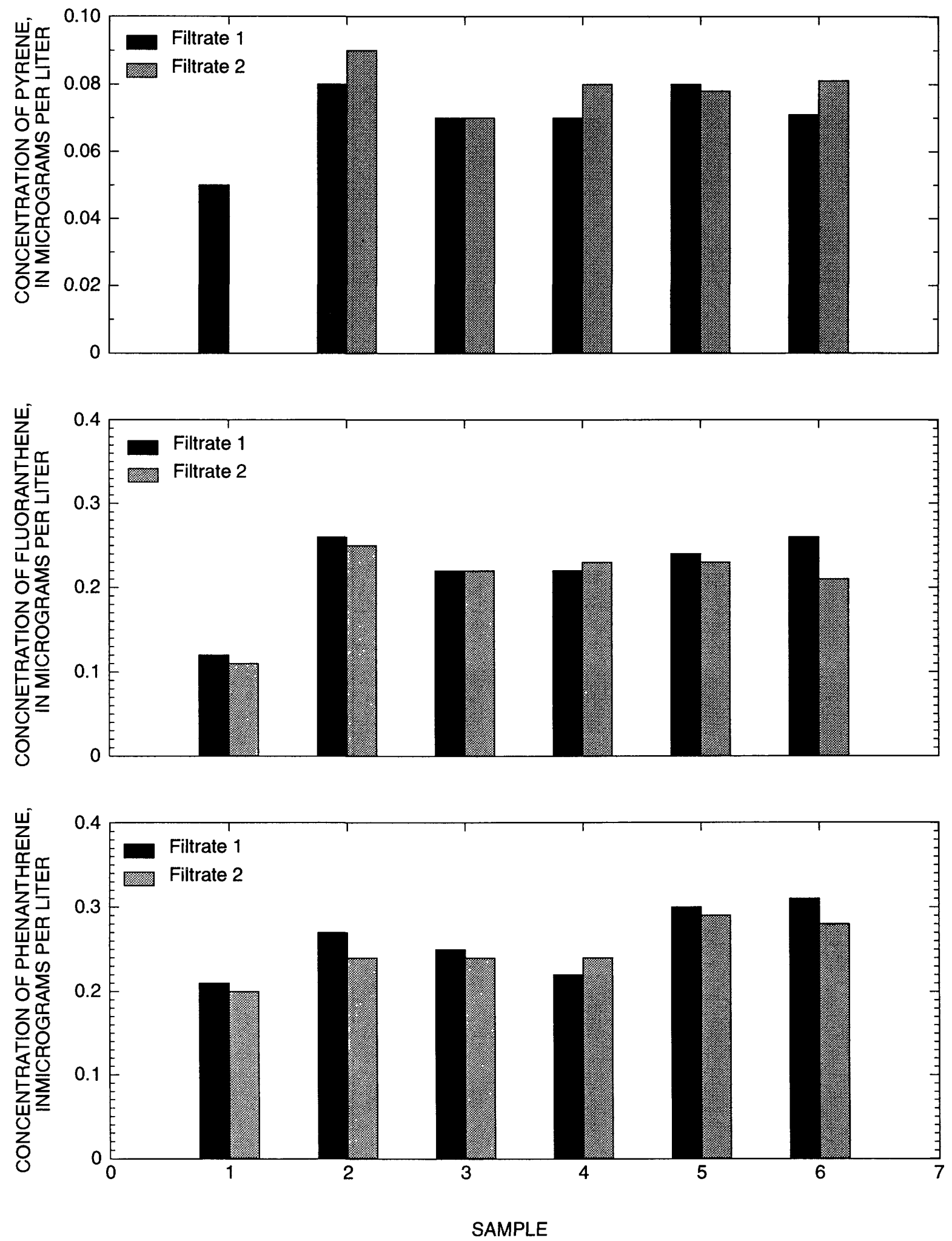

Figure 5. Comparison of polycyclic aromatic hydrocarbon samples filtered one time (filtrate 1) and two times (filtrate 2). 
water year 1993: U.S. Geological Survey Open-File Report 94-707, 57 p.

Graczyk, D.J., Walker, J.F., Greb, S.R., Corsi, S.R., and Owens, D.W., 1993, Evaluation of nonpoint-source contamination, Wisconsin-selected data for 1992 water year: U.S. Geological Survey Open-File Report 93-630, $48 \mathrm{p}$.

Holmstrom, B.K., Kammerer, P.A., Jr., and Erickson, R.M., 1986, Water resources data, Wisconsin, water year 1985: U.S. Geological Survey Water-Data Report WI-85-1, $414 \mathrm{p}$.

1987, Water resources data, Wisconsin, water year 1986: U.S. Geological Survey Water-Data Report WI-86-1, $402 \mathrm{p}$.

Holmstrom, B.K., and Erickson, R.M., 1989, Water resources data, Wisconsin, water year 1989: U.S. Geological Survey Water-Data Report WI-89-1, 436 p.

Holmstrom, B.K., Kammerer, P.A., Jr., and Erickson, R.M., 1990, Water resources data, Wisconsin, water year 1990: U.S. Geological Survey Water-Data Report WI-90-1, $578 \mathrm{p}$.

1991, Water resources data, Wisconsin, water year 1991: U.S. Geological Survey Water-Data Report WI-91-1, $607 \mathrm{p}$.

Holmstrom, B.K., Kammerer, P.A., Jr., and Ellefson, B.R., 1992, Water resources data, Wisconsin, water year 1992: U.S. Geological Survey Water-Data Report WI-92-1, $545 \mathrm{p}$.

1993, Water resources data, Wisconsin, water year 1993: U.S. Geological Survey Water-Data Report WI-93-1, 707 p.

1994, Water resources data, Wisconsin, water year 1994: U.S. Geological Survey Water-Data Report WI-94-1, 645 p.
1995, Water resources data, Wisconsin, water year 1994: U.S. Geological Survey Water-Data Report WI-95-1, $562 \mathrm{p}$.

Sandstrom, M.W., 1995, Filtration of water-sediment samples for the determination of organic compounds: U.S. Geological Survey Water-Resources Investigations Report 95-4105, 13 p.

Walker, J.F., 1994, Statistical techniques for assessing waterquality effects of BMPs: Journal of Irrigation and Drainage Engineering, v. 120, no. 2, p. 334-347.

Walker, J.F., Gracyzk, D.J., Corsi, S.R., Owens, D.W., and Wierl, J.A., 1995, Evaluation of nonpoint-source contamination, Wisconsin-Land-use and best-management practices inventory, selected streamwater-quality data, urban-watershed quality assurance and quality control, constituent loads in rural streams, and snowmelt-runoff analysis, water year 1994: U.S. Geological Survey Open-File Report 95-320, 21 p.

Walker, J.F., and Graczyk, D.J., 1993, Preliminary evaluation of effects of best management practices in Black Earth Creek, Wisconsin, priority watershed: Proceedings of 1st International IAWPRC Specialized Conference on Diffuse Pollution Sources, Prevention Impact and Abatement, Chicago, Ill., Sept. 20-24, 1993.

Wierl, J.A., Rappold, K.F., and Amerson, F.U., 1996, Summary of land-use inventory for nonpoint-source evaluation monitoring watersheds in Wisconsin, U.S. Geological Survey Open-File Report 96-123, 23 p.

Wisconsin Department of Natural Resources, 1994, WINHUSLE-model documentation and user's manual, version 1.4.4, report WR-294-91 [variously paged]. 
APPENDIXES 1-2 
Appendix 1. Storm-load data for rural watershed-management evaluation monitoring sites, Wisconsin, water years ${ }^{1}$ 1985-93

[yr, year; mo, month; d, day; h, hour; in., inches; $\mathrm{Mft}^{3}$, million cubic feet; lb, pounds; s/m, snowmelt; --, no data]

\begin{tabular}{|c|c|c|c|c|c|c|c|}
\hline \multicolumn{2}{|c|}{ Start of storm } & \multicolumn{2}{|c|}{ End of storm } & \multirow[b]{2}{*}{$\begin{array}{l}\text { Precipitation } \\
\text { (in.) }\end{array}$} & \multirow[b]{2}{*}{$\begin{array}{c}\text { Streamflow } \\
\text { volume } \\
\left(\mathrm{Mft}^{3}\right)\end{array}$} & \multicolumn{2}{|c|}{ Loads } \\
\hline $\begin{array}{c}\text { Date } \\
\text { (yr/mo/d) }\end{array}$ & $\begin{array}{l}\text { Time } \\
(24 \mathrm{~h})\end{array}$ & $\begin{array}{c}\text { Date } \\
(y r / m o / d)\end{array}$ & $\begin{array}{l}\text { Time } \\
(24 \mathrm{~h})\end{array}$ & & & $\begin{array}{l}\text { Suspended- } \\
\text { solids load } \\
\text { (tons) }\end{array}$ & $\begin{array}{c}\text { Total- } \\
\text { phosphorus } \\
\text { load } \\
\text { (lb) }\end{array}$ \\
\hline \multicolumn{8}{|c|}{ Brewery Creek } \\
\hline $84 / 10 / 18$ & 1745 & $84 / 10 / 19$ & 1700 & 2.78 & 1.5 & 35 & 140 \\
\hline $84 / 11 / 01$ & 0015 & $84 / 11 / 01$ & 2245 & .93 & .48 & 7.4 & 28 \\
\hline $84 / 12 / 28$ & 0045 & $84 / 12 / 28$ & 2145 & $\mathrm{~s} / \mathrm{m}$ & 1.3 & 22 & 180 \\
\hline $85 / 02 / 21$ & 0430 & $85 / 02 / 25$ & 0700 & $\mathrm{~s} / \mathrm{m}$ & 9.6 & 120 & 1,500 \\
\hline $85 / 07 / 24$ & 1930 & $85 / 07 / 26$ & 2230 & 6.85 & 14 & 500 & 2,000 \\
\hline $85 / 08 / 12$ & 2145 & $85 / 08 / 13$ & 1800 & .94 & .25 & 1.2 & 13 \\
\hline $85 / 08 / 25$ & 0200 & $85 / 08 / 26$ & 1000 & 1.70 & .53 & 2.6 & -- \\
\hline $85 / 09 / 04$ & 2330 & $85 / 09 / 05$ & 2115 & 1.53 & .56 & 2.3 & 38 \\
\hline $85 / 09 / 09$ & 0015 & $85 / 09 / 09$ & 2345 & 1.40 & 1.3 & 25 & 130 \\
\hline $85 / 10 / 12$ & 0315 & $85 / 10 / 13$ & 0200 & .80 & .76 & 3.3 & -- \\
\hline $85 / 10 / 23$ & 1515 & $85 / 10 / 24$ & 1400 & .59 & .39 & 2.3 & 20 \\
\hline $85 / 10 / 31$ & 1800 & $85 / 11 / 02$ & 1100 & 2.77 & 2.4 & 20 & 190 \\
\hline $85 / 11 / 17$ & 2245 & $85 / 11 / 19$ & 0800 & .63 & .85 & 3.5 & 55 \\
\hline $86 / 03 / 09$ & 2200 & $86 / 03 / 10$ & 2300 & $\mathrm{~s} / \mathrm{m}$ & .67 & 8.1 & -- \\
\hline $86 / 03 / 17$ & 1200 & $86 / 03 / 20$ & 0100 & $\mathrm{~s} / \mathrm{m}$ & 3.1 & 60 & 330 \\
\hline $86 / 05 / 15$ & 1500 & $86 / 05 / 16$ & 0200 & .58 & .28 & 1.2 & 18 \\
\hline $86 / 05 / 17$ & 0100 & $86 / 05 / 18$ & 0600 & 1.09 & .96 & 8.1 & 78 \\
\hline $86 / 06 / 22$ & 0100 & $86 / 06 / 22$ & 2300 & 1.16 & .77 & 1.1 & 24 \\
\hline $89 / 10 / 05$ & 0745 & $89 / 10 / 05$ & 1500 & -- & .020 & .040 & 1.1 \\
\hline $90 / 03 / 08$ & 0930 & $90 / 03 / 09$ & 0500 & .67 & 1.8 & 590 & 750 \\
\hline $90 / 03 / 11$ & 0600 & $90 / 03 / 12$ & 0200 & .50 & 2.5 & 160 & 820 \\
\hline $90 / 03 / 13$ & 1815 & $90 / 03 / 14$ & 0600 & .84 & .89 & 48 & 250 \\
\hline $90 / 06 / 02$ & 1315 & $90 / 06 / 03$ & 1000 & 1.54 & .59 & 35 & 140 \\
\hline $90 / 06 / 28$ & 2330 & $90 / 06 / 29$ & 1900 & 2.14 & 4.1 & 250 & 1,100 \\
\hline $91 / 04 / 12$ & 1230 & $91 / 04 / 13$ & 1230 & 1.17 & .75 & 8.3 & 85 \\
\hline $91 / 04 / 14$ & 0600 & $91 / 04 / 14$ & 2400 & .80 & .61 & 4.1 & 54 \\
\hline $91 / 04 / 28$ & 2045 & $91 / 04 / 29$ & 1100 & 1.24 & .29 & 7.1 & 47 \\
\hline $91 / 05 / 05$ & 0900 & $91 / 05 / 05$ & 2400 & 1.08 & .24 & 3.4 & 25 \\
\hline $91 / 07 / 01$ & 1415 & $91 / 07 / 02$ & 1500 & 1.29 & .34 & 1.7 & 27 \\
\hline $91 / 07 / 07$ & 1430 & $91 / 07 / 08$ & 1315 & 1.11 & .52 & 3.1 & 56 \\
\hline $91 / 08 / 08$ & 0130 & $91 / 08 / 08$ & 0900 & 2.24 & .14 & .97 & 9.9 \\
\hline $91 / 10 / 24$ & 2000 & $91 / 10 / 26$ & 0100 & 3.55 & 2.9 & 120 & 740 \\
\hline $91 / 11 / 01$ & 0030 & $91 / 11 / 02$ & 1330 & .81 & .88 & 5.4 & 90 \\
\hline $91 / 11 / 29$ & 1900 & $91 / 11 / 30$ & 1800 & .61 & .44 & 2.3 & 32 \\
\hline $92 / 02 / 27$ & 1030 & $92 / 02 / 28$ & 0500 & $\mathrm{~s} / \mathrm{m}$ & .87 & 6.7 & 130 \\
\hline $92 / 02 / 28$ & 0845 & $92 / 02 / 29$ & 0300 & $\mathrm{~s} / \mathrm{m}$ & .98 & 14 & 160 \\
\hline $92 / 03 / 01$ & 1200 & $92 / 03 / 02$ & 0700 & $\mathrm{~s} / \mathrm{m}$ & .66 & 20 & 120 \\
\hline
\end{tabular}


Appendix 1. Storm-load data for rural watershed-management evaluation monitoring sites, Wisconsin, water years ${ }^{1}$ 1985-93-Continued

[yr, year; mo, month; d, day; h, hour; in., inches; $\mathrm{Mft}^{3}$, million cubic feet; lb, pounds; s/m, snowmelt; --, no data]

\begin{tabular}{|c|c|c|c|c|c|c|c|}
\hline \multicolumn{2}{|c|}{ Start of storm } & \multicolumn{2}{|c|}{ End of storm } & \multirow[b]{2}{*}{$\begin{array}{l}\text { Precipitation } \\
\text { (in.) }\end{array}$} & \multirow[b]{2}{*}{$\begin{array}{c}\text { Streamflow } \\
\text { volume } \\
\left(\mathrm{Mft}^{3}\right)\end{array}$} & \multicolumn{2}{|c|}{ Loads } \\
\hline $\begin{array}{c}\text { Date } \\
\text { (yr/mo/d) }\end{array}$ & $\begin{array}{l}\text { Time } \\
(24 \mathrm{~h})\end{array}$ & $\begin{array}{c}\text { Date } \\
\text { (yr/mo/d) }\end{array}$ & $\begin{array}{l}\text { Time } \\
(24 \mathrm{~h})\end{array}$ & & & $\begin{array}{l}\text { Suspended- } \\
\text { solids load } \\
\text { (tons) }\end{array}$ & $\begin{array}{l}\text { Total- } \\
\text { phosphorus } \\
\text { load } \\
\text { (lb) }\end{array}$ \\
\hline \multicolumn{8}{|c|}{ Brewery Creek-Continued } \\
\hline $92 / 07 / 13$ & 1500 & $92 / 07 / 15$ & 0300 & 1.49 & .34 & -- & 36 \\
\hline $92 / 08 / 29$ & 0330 & $92 / 08 / 29$ & 1100 & 1.21 & .037 & .13 & .78 \\
\hline $92 / 09 / 16$ & 1100 & $92 / 09 / 17$ & 1800 & 1.19 & .25 & .51 & 27 \\
\hline $92 / 09 / 18$ & 0330 & $92 / 09 / 19$ & 1700 & .73 & .33 & .47 & 18 \\
\hline $92 / 10 / 15$ & 1800 & $92 / 10 / 15$ & 2300 & .45 & .019 & .020 & .28 \\
\hline $92 / 11 / 20$ & 0300 & $92 / 11 / 22$ & 0600 & 2.55 & 1.4 & 7.5 & 100 \\
\hline 93/03/06 & 1000 & 93/03/07 & 0815 & $\mathrm{~s} / \mathrm{m}$ & .60 & 13 & 440 \\
\hline $93 / 03 / 07$ & 1200 & $93 / 03 / 08$ & 0800 & $\mathrm{~s} / \mathrm{m}$ & 1.2 & 9.3 & 490 \\
\hline $93 / 03 / 08$ & 1300 & $93 / 03 / 09$ & 0400 & $\mathrm{~s} / \mathrm{m}$ & .83 & 7.8 & 380 \\
\hline $93 / 03 / 16$ & 0700 & $93 / 03 / 17$ & 0800 & $\mathrm{~s} / \mathrm{m}$ & 1.7 & 73 & 640 \\
\hline $93 / 03 / 24$ & 1000 & $93 / 03 / 25$ & 0700 & $\mathrm{~s} / \mathrm{m}$ & 2.1 & 36 & 330 \\
\hline $93 / 03 / 25$ & 1000 & $93 / 03 / 26$ & 0800 & $\mathrm{~s} / \mathrm{m}$ & 2.3 & 67 & 460 \\
\hline $93 / 03 / 26$ & 1200 & $93 / 03 / 27$ & 0800 & $\mathrm{~s} / \mathrm{m}$ & 2.3 & -- & 160 \\
\hline $93 / 03 / 27$ & 1200 & $93 / 03 / 28$ & 0800 & $\mathrm{~s} / \mathrm{m}$ & 1.2 & 16 & 98 \\
\hline $93 / 03 / 28$ & 1100 & $93 / 03 / 29$ & 0700 & $\mathrm{~s} / \mathrm{m}$ & 2.9 & 210 & 590 \\
\hline $93 / 03 / 31$ & 0300 & $93 / 04 / 01$ & 0300 & $\mathrm{~s} / \mathrm{m}$ & 2.5 & 55 & 250 \\
\hline $93 / 06 / 07$ & 1035 & $93 / 06 / 08$ & 1000 & 2.39 & 2.5 & 110 & 470 \\
\hline $93 / 06 / 17$ & 1000 & $93 / 06 / 18$ & 1200 & .43 & .93 & 18 & 67 \\
\hline $93 / 07 / 05$ & 0430 & $93 / 07 / 07$ & 0900 & 4.58 & 16 & 1,300 & 4,000 \\
\hline $93 / 07 / 07$ & 1800 & $93 / 07 / 08$ & 0900 & 1.03 & 1.3 & 130 & 460 \\
\hline $93 / 07 / 09$ & 0100 & $93 / 07 / 10$ & 0400 & 1.47 & 5.1 & 250 & 570 \\
\hline $93 / 07 / 17$ & 1100 & $93 / 07 / 18$ & 0400 & .86 & .84 & 42 & 87 \\
\hline $93 / 07 / 25$ & 0100 & $93 / 07 / 26$ & 0400 & 1.35 & 2.1 & 83 & 300 \\
\hline $93 / 07 / 27$ & 2200 & $93 / 07 / 28$ & 1900 & .88 & 1.4 & 25.8 & 120 \\
\hline $93 / 08 / 15$ & 0500 & $93 / 08 / 16$ & 2000 & 2.48 & 4.7 & 88.6 & 470 \\
\hline $93 / 09 / 13$ & 0800 & $93 / 09 / 15$ & 1500 & 2.12 & 2.9 & 12.1 & 130 \\
\hline $94 / 02 / 18$ & 1300 & $94 / 02 / 21$ & 1200 & -- & 4.9 & 220 & 780 \\
\hline $94 / 03 / 05$ & 1100 & $94 / 03 / 06$ & 0800 & -- & 2.8 & 72 & 510 \\
\hline $94 / 03 / 06$ & 0900 & $94 / 03 / 07$ & 0700 & -- & 1.7 & 30 & 110 \\
\hline $94 / 06 / 23$ & 1230 & $94 / 06 / 24$ & 2100 &.- & 1.2 & 4.2 & 62 \\
\hline $94 / 06 / 25$ & 2100 & $94 / 06 / 27$ & 0100 & -- & .66 & 2.1 & 16 \\
\hline $94 / 07 / 03$ & 2345 & $94 / 07 / 05$ & 2300 & -. & 5.9 & 200 & 930 \\
\hline $94 / 08 / 10$ & 1530 & $94 / 08 / 12$ & 0200 & -- & 1.1 & 2.5 & 32 \\
\hline $94 / 09 / 14$ & 0400 & $94 / 09 / 15$ & 0500 & -- & .65 & 4.1 & 36 \\
\hline
\end{tabular}


Appendix 1. Storm-load data for rural watershed-management evaluation monitoring sites, Wisconsin, water years ${ }^{1}$ 1985-93-Continued

[yr, year; mo, month; d, day; h, hour; in., inches; $\mathrm{Mft}^{3}$, million cubic feet; lb, pounds; s/m, snowmelt; -., no data]

\begin{tabular}{|c|c|c|c|c|c|c|c|}
\hline \multicolumn{2}{|c|}{ Start of storm } & \multicolumn{2}{|c|}{ End of storm } & \multirow[b]{2}{*}{$\begin{array}{l}\text { Precipitation } \\
\text { (in.) }\end{array}$} & \multirow[b]{2}{*}{$\begin{array}{c}\text { Streamflow } \\
\text { volume } \\
\left(\mathrm{Mft}^{3}\right)\end{array}$} & \multicolumn{2}{|c|}{ Loads } \\
\hline $\begin{array}{c}\text { Date } \\
\text { (yr/mo/d) }\end{array}$ & $\begin{array}{l}\text { Time } \\
(24 \mathrm{~h})\end{array}$ & $\begin{array}{c}\text { Date } \\
(\mathrm{yr} / \mathrm{mo} / \mathrm{d})\end{array}$ & $\begin{array}{l}\text { Time } \\
(24 \mathrm{~h})\end{array}$ & & & $\begin{array}{l}\text { Suspended- } \\
\text { solids load } \\
\text { (tons) }\end{array}$ & $\begin{array}{c}\text { Total- } \\
\text { phosphorus } \\
\text { load } \\
\text { (lb) }\end{array}$ \\
\hline \multicolumn{8}{|c|}{ Garfoot Creek } \\
\hline $84 / 10 / 18$ & 1200 & $84 / 10 / 19$ & 2200 & 2.64 & 3.1 & 37 & 210 \\
\hline $84 / 10 / 31$ & 2400 & $84 / 11 / 01$ & 1800 & 1.13 & 1.1 & 16 & 76 \\
\hline $84 / 12 / 27$ & 2200 & $84 / 12 / 29$ & 0900 & $\mathrm{~s} / \mathrm{m}$ & 2.4 & 45 & 140 \\
\hline $85 / 02 / 21$ & 0200 & $85 / 02 / 25$ & 0100 & $\mathrm{~s} / \mathrm{m}$ & 6.3 & 62 & 470 \\
\hline $85 / 07 / 24$ & 1915 & $85 / 07 / 26$ & 0500 & 6.56 & 7.5 & 65 & 710 \\
\hline $85 / 09 / 04$ & 2400 & $85 / 09 / 05$ & 1300 & 1.38 & .49 & 1.7 & 22 \\
\hline $85 / 09 / 09$ & 0015 & $85 / 09 / 09$ & 2100 & 1.63 & 2.2 & 17 & 130 \\
\hline $85 / 09 / 23$ & 0300 & $85 / 09 / 24$ & 0300 & 1.20 & .57 & 1.9 & - \\
\hline $85 / 10 / 11$ & 2345 & $85 / 10 / 12$ & 2100 & .85 & 1.1 & 14 & -- \\
\hline $85 / 10 / 23$ & 1600 & $85 / 10 / 24$ & 0700 & .70 & .62 & 9.8 & 46 \\
\hline $85 / 10 / 31$ & 1626 & $85 / 11 / 02$ & 1400 & 2.79 & 5.3 & 34 & 370 \\
\hline $85 / 11 / 18$ & 0300 & $85 / 11 / 19$ & 0900 & .73 & 1.6 & 17 & 98 \\
\hline $86 / 03 / 09$ & 1600 & $86 / 03 / 11$ & 0600 & $\mathrm{~s} / \mathrm{m}$ & 1.7 & 26 & 110 \\
\hline $86 / 03 / 16$ & 1200 & $86 / 03 / 20$ & 0200 & $\mathrm{~s} / \mathrm{m}$ & 7.7 & 59 & 610 \\
\hline $86 / 05 / 15$ & 1400 & $86 / 05 / 16$ & 0500 & .72 & .53 & 14 & 27 \\
\hline $86 / 05 / 17$ & 0100 & $86 / 05 / 18$ & 0400 & 1.15 & 1.2 & 15 & 75 \\
\hline $89 / 10 / 05$ & 0930 & $89 / 10 / 06$ & 0600 & -- & .21 & .27 & 6.4 \\
\hline $90 / 01 / 16$ & 1845 & $90 / 01 / 17$ & 2200 & $\mathrm{~s} / \mathrm{m}$ & 1.4 & 13 & 190 \\
\hline $90 / 03 / 11$ & 0600 & $90 / 03 / 12$ & 0400 & .48 & 2.9 & 53 & 330 \\
\hline $90 / 03 / 13$ & 0600 & $90 / 03 / 14$ & 1300 & .76 & 1.3 & 30 & 160 \\
\hline $90 / 03 / 14$ & 1600 & $90 / 03 / 15$ & 1500 & 1.12 & 2.0 & 31 & 230 \\
\hline $90 / 06 / 02$ & 1300 & $90 / 06 / 03$ & 0100 & 1.48 & .42 & 23 & 100 \\
\hline $90 / 06 / 28$ & 2330 & $90 / 06 / 29$ & 2300 & 2.45 & 3.0 & 77 & 530 \\
\hline $90 / 08 / 19$ & 1630 & $90 / 08 / 20$ & 1200 & -- & .81 & 4.6 & 61 \\
\hline $91 / 03 / 01$ & 0945 & $91 / 03 / 02$ & 2200 & 1.51 & 3.2 & 53 & 370 \\
\hline $91 / 03 / 22$ & 2130 & $91 / 03 / 23$ & 0700 & .74 & .33 & 4.2 & 28 \\
\hline $91 / 04 / 12$ & 1500 & $91 / 04 / 13$ & 1400 & 1.74 & 2.2 & 74 & 210 \\
\hline $91 / 04 / 14$ & 0600 & $91 / 04 / 14$ & 2400 & .99 & 1.9 & 58 & 200 \\
\hline $91 / 08 / 08$ & 0200 & $91 / 08 / 08$ & 1500 & 2.34 & .30 & -- & 12 \\
\hline $91 / 11 / 01$ & 0900 & $91 / 11 / 02$ & 0100 & 1.40 & 1.3 & 15 & 150 \\
\hline $91 / 11 / 29$ & 2000 & $91 / 11 / 30$ & 1300 & .87 & .98 & 13 & 76 \\
\hline $92 / 02 / 26$ & 1400 & $92 / 02 / 27$ & 0100 & $\mathrm{~s} / \mathrm{m}$ & .30 & -- & 11 \\
\hline $92 / 02 / 27$ & 1045 & $92 / 02 / 28$ & 0100 & $\mathrm{~s} / \mathrm{m}$ & .68 & 9.0 & 54 \\
\hline $92 / 02 / 28$ & 1130 & $92 / 02 / 28$ & 2400 & $\mathrm{~s} / \mathrm{m}$ & .44 & 1.5 & 21 \\
\hline $92 / 09 / 16$ & 1200 & $92 / 09 / 17$ & 0330 & 1.34 & .69 & 7.4 & 46 \\
\hline $92 / 09 / 18$ & 0330 & $92 / 09 / 18$ & 1800 & .89 & .70 & 5.2 & 48 \\
\hline $92 / 11 / 19$ & 2000 & $92 / 11 / 21$ & 2300 & 2.68 & 3.4 & 43 & 420 \\
\hline
\end{tabular}


Appendix 1. Storm-load data for rural watershed-management evaluation monitoring sites, Wisconsin, water years ${ }^{1}$ 1985-93-Continued

[yr, year; mo, month; d, day; h, hour; in., inches; $\mathrm{Mft}^{3}$, million cubic feet; lb, pounds; s/m, snowmelt; --, no data]

\begin{tabular}{|c|c|c|c|c|c|c|c|}
\hline \multicolumn{2}{|c|}{ Start of storm } & \multicolumn{2}{|c|}{ End of storm } & \multirow[b]{2}{*}{$\begin{array}{l}\text { Precipitation } \\
\text { (in.) }\end{array}$} & \multirow[b]{2}{*}{$\begin{array}{c}\text { Streamflow } \\
\text { volume } \\
\left(\mathrm{Mft}^{3}\right)\end{array}$} & \multicolumn{2}{|c|}{ Loads } \\
\hline $\begin{array}{c}\text { Date } \\
\text { (yr/mo/d) }\end{array}$ & $\begin{array}{l}\text { Time } \\
(24 \mathrm{~h})\end{array}$ & $\begin{array}{c}\text { Date } \\
\text { (yr/mo/d) }\end{array}$ & $\begin{array}{l}\text { Time } \\
(24 \mathrm{~h})\end{array}$ & & & $\begin{array}{l}\text { Suspended- } \\
\text { solids load } \\
\text { (tons) }\end{array}$ & $\begin{array}{c}\text { Total- } \\
\text { phosphorus } \\
\text { load } \\
\text { (lb) }\end{array}$ \\
\hline \multicolumn{8}{|c|}{ Garfoot Creek-Continued } \\
\hline $92 / 12 / 15$ & 1600 & $92 / 12 / 16$ & 1200 & 1.30 & 1.2 & 7.4 & 400 \\
\hline $93 / 03 / 24$ & 1300 & $93 / 03 / 25$ & 0830 & $\mathrm{~s} / \mathrm{m}$ & 2.1 & 24 & 240 \\
\hline $93 / 03 / 25$ & 1030 & $93 / 03 / 26$ & 1000 & $\mathrm{~s} / \mathrm{m}$ & 3.4 & 41 & 300 \\
\hline $93 / 03 / 26$ & 1300 & $93 / 03 / 27$ & 0500 & $\mathrm{~s} / \mathrm{m}$ & 1.7 & 14 & 130 \\
\hline $93 / 03 / 27$ & 1240 & $93 / 03 / 28$ & 0400 & $\mathrm{~s} / \mathrm{m}$ & 1.3 & 9.1 & 100 \\
\hline $93 / 03 / 28$ & 1000 & $93 / 03 / 29$ & 0300 & $\mathrm{~s} / \mathrm{m}$ & 2.7 & 44 & 290 \\
\hline $93 / 03 / 31$ & 0400 & $93 / 04 / 01$ & 0400 & $\mathrm{~s} / \mathrm{m}$ & 3.7 & 28 & 210 \\
\hline $93 / 04 / 07$ & 2300 & $93 / 04 / 08$ & 1700 & .62 & 1.3 & 13 & 60 \\
\hline $93 / 04 / 15$ & 0100 & $93 / 04 / 16$ & 1200 & 1.55 & 4.2 & 35 & 240 \\
\hline $93 / 04 / 19$ & 1300 & $93 / 04 / 20$ & 2300 & 1.69 & 3.8 & 37 & 180 \\
\hline $93 / 06 / 07$ & 1045 & $93 / 06 / 08$ & 2000 & 1.97 & 2.8 & 31 & 180 \\
\hline $93 / 06 / 17$ & 1800 & $93 / 06 / 18$ & 1200 & 1.09 & .99 & 13 & 54 \\
\hline $93 / 07 / 05$ & 0500 & $93 / 07 / 07$ & 0200 & 3.98 & 7.7 & 130 & 730 \\
\hline $93 / 07 / 08$ & 1300 & $93 / 07 / 10$ & 0400 & 1.81 & 5.9 & 110 & 490 \\
\hline $93 / 07 / 10$ & 1800 & $93 / 07 / 11$ & 0500 & .45 & 1.1 & 12 & 63 \\
\hline $93 / 07 / 25$ & 0300 & $93 / 07 / 25$ & 2400 & 1.48 & 2.5 & 43 & 220 \\
\hline $93 / 07 / 27$ & 2200 & $93 / 07 / 28$ & 1500 & .44 & .92 & 5.92 & 38 \\
\hline $93 / 08 / 15$ & 0500 & $93 / 08 / 16$ & 1300 & 2.35 & 3.6 & 30.8 & 230 \\
\hline $93 / 08 / 23$ & 1600 & $93 / 08 / 24$ & 0700 & 1.26 & 1.3 & 14.2 & 65 \\
\hline $93 / 09 / 13$ & 1000 & $93 / 09 / 15$ & 0500 & 2.27 & 2.7 & 18.6 & 140 \\
\hline $94 / 02 / 19$ & 0100 & $94 / 02 / 21$ & 0700 & -- & 6.4 & 74 & 650 \\
\hline $94 / 03 / 05$ & 1200 & $94 / 03 / 06$ & 0500 & -- & 1.2 & 9 & 89 \\
\hline $94 / 03 / 06$ & 1100 & $94 / 03 / 07$ & 0500 & -- & 1.2 & 5.7 & 63 \\
\hline $94 / 08 / 10$ & 1200 & $94 / 08 / 11$ & 1500 & -- & 1.4 & 12 & 76 \\
\hline $94 / 09 / 14$ & 0500 & $94 / 09 / 14$ & 2000 & -- & .59 & 5.2 & 22 \\
\hline \multicolumn{8}{|c|}{ Eagle Creek } \\
\hline $91 / 04 / 29$ & 0200 & $91 / 04 / 29$ & 2200 & 1.81 & 5.1 & 2,100 & 3,800 \\
\hline $91 / 05 / 05$ & 0800 & $91 / 05 / 05$ & 2230 & 1.29 & 1.7 & 61 & 210 \\
\hline $91 / 05 / 15$ & 2130 & $91 / 05 / 17$ & 0200 & .85 & 6.9 & 3,200 & 4,700 \\
\hline $91 / 05 / 31$ & 0900 & $91 / 05 / 31$ & 2000 & .50 & 1.2 & 250 & 280 \\
\hline $91 / 07 / 21$ & 1715 & $91 / 07 / 21$ & 2400 & 1.99 & 1.6 & 220 & 430 \\
\hline $91 / 08 / 07$ & 1540 & $91 / 08 / 08$ & 1500 & 1.88 & 1.6 & 62 & 140 \\
\hline $91 / 10 / 23$ & 2325 & $91 / 10 / 24$ & 1200 & 1.21 & .88 & 52 & 200 \\
\hline $91 / 11 / 01$ & 0050 & $91 / 11 / 01$ & 2300 & 2.75 & 7.0 & 620 & 1,400 \\
\hline $91 / 11 / 17$ & 1900 & $91 / 11 / 18$ & 1200 & 1.15 & 1.9 & 120 & 250 \\
\hline $92 / 03 / 01$ & 1100 & $92 / 03 / 02$ & 0400 & $\mathrm{~s} / \mathrm{m}$ & 1.3 & 140 & 220 \\
\hline
\end{tabular}


Appendix 1. Storm-load data for rural watershed-management evaluation monitoring sites, Wisconsin, water years ${ }^{1}$ 1985-93-Continued

[yr, year; mo, month; d, day; h, hour; in., inches; $\mathrm{Mft}^{3}$, million cubic feet; lb, pounds; $\mathrm{s} / \mathrm{m}$, snowmelt; --, no data]

\begin{tabular}{|c|c|c|c|c|c|c|c|}
\hline \multicolumn{2}{|c|}{ Start of storm } & \multicolumn{2}{|c|}{ End of storm } & \multirow[b]{2}{*}{$\begin{array}{l}\text { Precipitation } \\
\text { (in.) }\end{array}$} & \multirow[b]{2}{*}{$\begin{array}{c}\text { Streamflow } \\
\text { volume } \\
\left(\mathrm{Mft}^{3}\right)\end{array}$} & \multicolumn{2}{|c|}{ Loads } \\
\hline $\begin{array}{c}\text { Date } \\
\text { (yr/mo/d) }\end{array}$ & $\begin{array}{l}\text { Time } \\
(24 \mathrm{~h})\end{array}$ & $\begin{array}{c}\text { Date } \\
\text { (yr/mo/d) }\end{array}$ & $\begin{array}{l}\text { Time } \\
(24 \mathrm{~h})\end{array}$ & & & $\begin{array}{l}\text { Suspended- } \\
\text { solids load } \\
\text { (tons) }\end{array}$ & $\begin{array}{c}\text { Total- } \\
\text { phosphorus } \\
\text { load } \\
\text { (lb) }\end{array}$ \\
\hline \multicolumn{8}{|c|}{ Eagle Creek-Continued } \\
\hline $92 / 03 / 03$ & 2000 & $92 / 03 / 04$ & 0900 & .41 & .92 & 48 & 130 \\
\hline $92 / 03 / 09$ & 0100 & $92 / 03 / 09$ & 1300 & .82 & 1.1 & 72 & 170 \\
\hline $92 / 04 / 20$ & 1500 & $92 / 04 / 21$ & 0900 & 1.24 & 1.8 & 210 & 300 \\
\hline $92 / 05 / 16$ & 1645 & $92 / 05 / 16$ & 2400 & 1.54 & .66 & 83.6 & 160 \\
\hline $92 / 05 / 21$ & 1730 & $92 / 05 / 21$ & 2200 & .51 & .24 & 6.3 & 22 \\
\hline $92 / 05 / 22$ & 1815 & $92 / 05 / 23$ & 0300 & .44 & .47 & 26 & 84 \\
\hline $92 / 07 / 13$ & 1400 & $92 / 07 / 13$ & 2400 & 1.27 & .73 & 43 & 80 \\
\hline $92 / 08 / 01$ & 1900 & $92 / 08 / 02$ & 0200 & 1.03 & .49 & 16 & 31 \\
\hline $92 / 09 / 16$ & 0200 & $92 / 09 / 16$ & 2400 & 3.99 & 1.2 & 1,700 & 3,300 \\
\hline $93 / 03 / 26$ & 1200 & $93 / 03 / 27$ & 0200 & $\mathrm{~s} / \mathrm{m}$ & 1.1 & 35 & 87 \\
\hline $93 / 03 / 29$ & 1100 & $93 / 03 / 29$ & 2400 & $\mathrm{~s} / \mathrm{m}$ & 9.9 & 27 & 42 \\
\hline $93 / 03 / 30$ & 1300 & $93 / 03 / 31$ & 2100 & 1.67 & 4.7 & 420 & 610 \\
\hline $93 / 04 / 11$ & 0200 & $93 / 04 / 12$ & 0600 & .79 & 2.4 & 50 & 100 \\
\hline $93 / 04 / 18$ & 2100 & $93 / 04 / 20$ & 0600 & 2.22 & 7.0 & 450 & 960 \\
\hline $93 / 04 / 27$ & 0100 & $93 / 04 / 27$ & 1400 & 1.02 & 1.4 & 74 & 180 \\
\hline $93 / 06 / 08$ & 1500 & $93 / 06 / 09$ & 0400 & 1.47 & 4.4 & 950 & 2,000 \\
\hline $93 / 07 / 02$ & 0010 & $93 / 07 / 02$ & 1100 & 1.47 & 5.5 & 420 & 1,100 \\
\hline $93 / 07 / 03$ & 1400 & $93 / 07 / 04$ & 0600 & 1.06 & 6.1 & 1,500 & 3,000 \\
\hline $93 / 07 / 27$ & 1715 & $93 / 07 / 28$ & 0400 & .76 & 1.5 & 120 & 220 \\
\hline $93 / 08 / 09$ & 0600 & $93 / 08 / 09$ & 2000 & 1.09 & 2.8 & 310 & 540 \\
\hline $93 / 08 / 15$ & 0400 & $93 / 08 / 15$ & 1800 & 1.18 & 2.2 & 73 & 160 \\
\hline $93 / 08 / 18$ & 0900 & $93 / 08 / 18$ & 2100 & 1.30 & 3.6 & 290 & 640 \\
\hline $93 / 08 / 30$ & 0400 & $93 / 08 / 30$ & 2000 & 1.69 & 4.6 & 410 & 1,000 \\
\hline $93 / 09 / 13$ & 1000 & $93 / 09 / 14$ & 1100 & 1.72 & 3.6 & 120 & 300 \\
\hline $94 / 02 / 18$ & 1300 & $94 / 02 / 20$ & 0900 & -- & 12 & 1,700 & 3,400 \\
\hline $94 / 03 / 04$ & 1100 & $94 / 03 / 05$ & 0800 & -- & 3.6 & 380 & 790 \\
\hline $94 / 03 / 05$ & 1100 & $94 / 03 / 06$ & 1000 & -- & 2.9 & 130 & 450 \\
\hline $94 / 04 / 15$ & 0140 & $94 / 04 / 16$ & 0600 & -- & 2.2 & 67 & 140 \\
\hline $94 / 04 / 24$ & 2000 & $94 / 04 / 25$ & 1900 & -- & 2.0 & 54 & 110 \\
\hline $94 / 04 / 26$ & 0010 & $94 / 04 / 27$ & 0200 & +- & 5.2 & 1,900 & 2,900 \\
\hline $94 / 07 / 07$ & 1300 & $94 / 07 / 08$ & 1100 & .. & 1.9 & 75 & 170 \\
\hline $94 / 08 / 10$ & 0110 & $94 / 08 / 11$ & 1000 & -- & 6.0 & 390 & 800 \\
\hline $94 / 08 / 18$ & 0315 & $94 / 08 / 18$ & 2100 & -- & 1.7 & 95 & 180 \\
\hline $94 / 08 / 30$ & 0835 & $94 / 08 / 31$ & 0300 & -- & 1.5 & 51 & 110 \\
\hline $94 / 09 / 13$ & 2035 & $94 / 09 / 15$ & 0300 & -- & 5.5 & 340 & 920 \\
\hline $94 / 09 / 23$ & 1615 & $94 / 09 / 24$ & 1100 & -- & 1.4 & 30 & 63 \\
\hline
\end{tabular}


Appendix 1. Storm-load data for rural watershed-management evaluation monitoring sites, Wisconsin, water years ${ }^{1}$ 1985-93-Continued

[yr, year; mo, month; d, day; h, hour; in., inches; $\mathrm{Mft}^{3}$, million cubic feet; lb, pounds; s/m, snowmelt; --, no data]

\begin{tabular}{|c|c|c|c|c|c|c|c|}
\hline \multicolumn{2}{|c|}{ Start of storm } & \multicolumn{2}{|c|}{ End of storm } & \multirow[b]{2}{*}{$\begin{array}{l}\text { Precipitation } \\
\text { (in.) }\end{array}$} & \multirow[b]{2}{*}{$\begin{array}{l}\text { Streamflow } \\
\text { volume } \\
\left(\mathrm{Mft}^{3}\right)\end{array}$} & \multicolumn{2}{|c|}{ Loads } \\
\hline $\begin{array}{c}\text { Date } \\
\text { (yr/mo/d) }\end{array}$ & $\begin{array}{l}\text { Time } \\
(24 \mathrm{~h})\end{array}$ & $\begin{array}{c}\text { Date } \\
\text { (yr/mo/d) }\end{array}$ & $\begin{array}{l}\text { Time } \\
(24 \mathrm{~h})\end{array}$ & & & $\begin{array}{l}\text { Suspended- } \\
\text { solids load } \\
\text { (tons) }\end{array}$ & $\begin{array}{c}\text { Total- } \\
\text { phosphorus } \\
\text { load } \\
\text { (lb) }\end{array}$ \\
\hline \multicolumn{8}{|c|}{ Joos Valley Creek } \\
\hline $90 / 08 / 17$ & 1850 & $90 / 08 / 18$ & 0200 & 1.37 & .96 & 170 & 420 \\
\hline $90 / 08 / 26$ & 0545 & $90 / 08 / 26$ & 1500 & 1.75 & 2.8 & 750 & 1,600 \\
\hline $91 / 04 / 29$ & 0200 & $91 / 04 / 29$ & 1600 & 2.11 & 1.7 & 840 & 1,500 \\
\hline $91 / 05 / 05$ & 0730 & $91 / 05 / 05$ & 2000 & 1.25 & .64 & 26 & 57 \\
\hline $91 / 05 / 15$ & 2000 & $91 / 05 / 17$ & 0200 & 1.21 & 1.8 & 390 & 850 \\
\hline $91 / 05 / 31$ & 0850 & $91 / 05 / 31$ & 1900 & .57 & .40 & 36 & 78 \\
\hline $91 / 07 / 21$ & 1710 & $91 / 07 / 22$ & 1100 & 1.24 & .68 & 27 & 70 \\
\hline $91 / 08 / 07$ & 1500 & $91 / 08 / 08$ & 1100 & 2.27 & .63 & 11 & 34 \\
\hline $91 / 10 / 23$ & 2250 & $91 / 10 / 24$ & 1300 & .83 & .34 & 3.4 & 12 \\
\hline $91 / 10 / 31$ & 2200 & $91 / 11 / 01$ & 2200 & 2.87 & 2.1 & 110 & 330 \\
\hline $91 / 11 / 17$ & 1800 & $91 / 11 / 18$ & 1400 & 1.21 & .96 & 14 & 62 \\
\hline $92 / 03 / 01$ & 1000 & $92 / 03 / 02$ & 0400 & $\mathrm{~s} / \mathrm{m}$ & .63 & 16 & 68 \\
\hline $92 / 03 / 03$ & 1400 & $92 / 03 / 04$ & 0800 & .37 & .47 & 1.5 & 11 \\
\hline $92 / 03 / 08$ & 2400 & $92 / 03 / 09$ & 1100 & .86 & .45 & 20 & 49 \\
\hline $92 / 04 / 20$ & 1300 & $92 / 04 / 21$ & 0700 & 1.24 & .77 & 56 & 120 \\
\hline $92 / 05 / 16$ & 1500 & $92 / 05 / 16$ & 2200 & 1.62 & .34 & 54 & 110 \\
\hline $92 / 05 / 21$ & 1700 & $92 / 05 / 21$ & 2400 & .74 & .22 & 13 & 35 \\
\hline $92 / 05 / 22$ & 1800 & $92 / 05 / 23$ & 0300 & .49 & .27 & 12 & 31 \\
\hline $92 / 06 / 17$ & 0400 & $92 / 06 / 17$ & 1800 & .57 & .25 & 2.8 & 7.7 \\
\hline $92 / 07 / 02$ & 0500 & $92 / 07 / 02$ & 1500 & .72 & .23 & 4.2 & 9.2 \\
\hline $92 / 07 / 13$ & 1300 & $92 / 07 / 14$ & 0200 & 1.32 & .40 & 7.1 & 21 \\
\hline $92 / 07 / 22$ & 1000 & $92 / 07 / 23$ & 0300 & 1.19 & .37 & 1.4 & 5.7 \\
\hline $92 / 08 / 01$ & 1800 & $92 / 08 / 02$ & 1300 & 1.24 & .57 & 24 & 73 \\
\hline $92 / 09 / 16$ & 0100 & $92 / 09 / 16$ & 2200 & 4.19 & 5.4 & 910 & 1,700 \\
\hline $93 / 03 / 24$ & 1100 & $93 / 03 / 25$ & 0500 & $\mathrm{~s} / \mathrm{m}$ & .38 & 1.4 & 14 \\
\hline $93 / 03 / 26$ & 1300 & $93 / 03 / 27$ & 0200 & $\mathrm{~s} / \mathrm{m}$ & .47 & 8.3 & 56 \\
\hline $93 / 03 / 30$ & 1100 & $93 / 03 / 31$ & 2000 & 1.50 & 2.1 & 86 & 25 \\
\hline $93 / 04 / 11$ & 0100 & $93 / 04 / 12$ & 0200 & .53 & .87 & 4.0 & 15 \\
\hline $93 / 04 / 16$ & 1200 & $93 / 04 / 17$ & 0100 & .64 & .60 & 4.2 & 16 \\
\hline $93 / 04 / 18$ & 2200 & $93 / 04 / 20$ & 0300 & 2.07 & 2.7 & 130 & 320 \\
\hline $93 / 04 / 27$ & 0100 & $93 / 04 / 28$ & 0200 & 1.07 & 1.5 & 22 & 63 \\
\hline $93 / 06 / 08$ & 1500 & $93 / 06 / 08$ & 2310 & 1.50 & 1.8 & 630 & 900 \\
\hline $93 / 07 / 01$ & 2400 & $93 / 07 / 02$ & 0940 & 1.33 & 1.2 & 180 & 410 \\
\hline $93 / 07 / 03$ & 1400 & $93 / 07 / 03$ & 2100 & .90 & 2.2 & 880 & 1,600 \\
\hline $93 / 07 / 27$ & 1700 & $93 / 07 / 27$ & 2300 & .75 & .54 & 64 & 130 \\
\hline $93 / 08 / 09$ & 0600 & $93 / 08 / 09$ & 1400 & 1.17 & .92 & 110 & 220 \\
\hline
\end{tabular}


Appendix 1. Storm-load data for rural watershed-management evaluation monitoring sites, Wisconsin, water years ${ }^{1}$ 1985-93-Continued

[yr, year; mo, month; d, day; h, hour; in., inches; $\mathrm{Mft}^{3}$, million cubic feet; lb, pounds; s/m, snowmelt; --, no data]

\begin{tabular}{|c|c|c|c|c|c|c|c|}
\hline \multicolumn{2}{|c|}{ Start of storm } & \multicolumn{2}{|c|}{ End of storm } & \multirow[b]{2}{*}{$\begin{array}{l}\text { Precipitation } \\
\text { (in.) }\end{array}$} & \multirow[b]{2}{*}{$\begin{array}{l}\text { Streamflow } \\
\text { volume } \\
\left(\mathrm{Mft}^{3}\right)\end{array}$} & \multicolumn{2}{|c|}{ Loads } \\
\hline $\begin{array}{c}\text { Date } \\
\text { (yr/mo/d) }\end{array}$ & $\begin{array}{c}\text { Time } \\
(24 \mathrm{~h})\end{array}$ & $\begin{array}{c}\text { Date } \\
(y \mathrm{yr} / \mathrm{mo} / \mathrm{d})\end{array}$ & $\begin{array}{l}\text { Time } \\
(24 \mathrm{~h})\end{array}$ & & & $\begin{array}{l}\text { Suspended- } \\
\text { solids load } \\
\text { (tons) }\end{array}$ & $\begin{array}{c}\text { Total- } \\
\text { phosphorus } \\
\text { load } \\
\text { (lb) }\end{array}$ \\
\hline \multicolumn{8}{|c|}{ Joos Valley Creek-Continued } \\
\hline $93 / 08 / 15$ & 0300 & $93 / 08 / 15$ & 1500 & 1.19 & .73 & 12 & 330 \\
\hline $93 / 08 / 18$ & 0900 & $93 / 08 / 18$ & 0900 & 1.08 & .87 & 53 & 140 \\
\hline $93 / 08 / 30$ & 0300 & $93 / 08 / 30$ & 1300 & 1.78 & 1.4 & 130 & 290 \\
\hline $94 / 02 / 18$ & 1200 & $94 / 02 / 20$ & 0800 & -- & 5.7 & 740 & 1500 \\
\hline $94 / 03 / 04$ & 1000 & $94 / 03 / 05$ & 0500 & -- & 1.8 & 160 & 350 \\
\hline $94 / 03 / 05$ & 1100 & $94 / 03 / 06$ & 0800 & -- & 1.3 & 28 & 250 \\
\hline $94 / 04 / 15$ & 0110 & $94 / 04 / 16$ & 0300 & -- & .84 & 16 & 35 \\
\hline $94 / 04 / 24$ & 2110 & $94 / 04 / 26$ & 2100 & -- & 2.8 & 670 & 1,200 \\
\hline $94 / 07 / 07$ & 1122 & $94 / 07 / 08$ & 1000 & -- & .77 & 19 & 60 \\
\hline $94 / 08 / 10$ & 0425 & $94 / 08 / 11$ & 1900 & -- & 2.3 & 130 & 300 \\
\hline $94 / 08 / 18$ & 0325 & $94 / 08 / 18$ & 2300 & -- & .68 & 22 & 70 \\
\hline $94 / 08 / 13$ & 0740 & $94 / 08 / 30$ & 2100 & - & .5 & 5.1 & 17 \\
\hline $94 / 09 / 13$ & 2035 & $94 / 09 / 14$ & 2300 & -- & 2.1 & 150 & 420 \\
\hline $94 / 09 / 23$ & 1550 & $94 / 09 / 23$ & 2300 & - & .31 & 4.2 & 9.5 \\
\hline \multicolumn{8}{|c|}{ Bower Creek } \\
\hline $90 / 10 / 17$ & 2040 & $90 / 10 / 20$ & 0925 & .38 & 3.6 & 12 & 280 \\
\hline $91 / 03 / 01$ & 1500 & $91 / 03 / 04$ & 1100 & 1.05 & 100 & 100 & -- \\
\hline $91 / 03 / 05$ & 1700 & $91 / 03 / 08$ & 1500 & $\mathrm{~s} / \mathrm{m}$ & 12 & 13 & 520 \\
\hline $91 / 03 / 18$ & 1300 & $91 / 03 / 25$ & 0900 & $\mathrm{~s} / \mathrm{m}$ & 160 & 160 & 1,800 \\
\hline $91 / 04 / 09$ & 1100 & $91 / 04 / 12$ & 2000 & $\mathrm{~s} / \mathrm{m}$ & 48 & 48 & 460 \\
\hline $91 / 04 / 12$ & 2400 & $91 / 04 / 17$ & 2400 & .71 & 260 & 260 & 1,500 \\
\hline $91 / 06 / 14$ & 0500 & $91 / 06 / 15$ & 1545 & 1.40 & 1.2 & 9.7 & 70 \\
\hline $91 / 10 / 29$ & 1000 & $91 / 10 / 31$ & 1400 & 1.02 & 1.00 & 1.8 & 58 \\
\hline $91 / 11 / 01$ & 1325 & $91 / 11 / 04$ & 0600 & .35 & .91 & .55 & 77 \\
\hline $91 / 11 / 18$ & 0700 & $91 / 11 / 20$ & 0905 & .23 & .90 & .24 & 32 \\
\hline $91 / 11 / 29$ & 1805 & $91 / 12 / 02$ & 1610 & .78 & 10 & 64 & 590 \\
\hline $91 / 12 / 12$ & 0825 & $91 / 12 / 14$ & 0700 & .61 & 14 & 64 & 700 \\
\hline $92 / 03 / 29$ & 1500 & $92 / 03 / 31$ & 0940 & .28 & 3.9 & 5.9 & 120 \\
\hline $92 / 03 / 31$ & 1200 & $92 / 04 / 02$ & 1100 & .12 & 3.9 & 11 & 150 \\
\hline $92 / 04 / 10$ & 1700 & $92 / 04 / 13$ & 1535 & .43 & 12 & 75 & 440 \\
\hline $92 / 04 / 15$ & 1200 & $92 / 04 / 18$ & 0935 & 2.07 & 34 & 710 & 2,900 \\
\hline $92 / 04 / 19$ & 1355 & $92 / 04 / 20$ & 1815 & .19 & 3.4 & 11 & 110 \\
\hline $92 / 04 / 20$ & 1945 & $92 / 04 / 22$ & 0910 & .36 & 7.2 & 72 & 430 \\
\hline $92 / 07 / 13$ & 1820 & $92 / 07 / 16$ & 0500 & .71 & .48 & .24 & 13 \\
\hline $92 / 09 / 16$ & 0725 & $92 / 09 / 17$ & 0520 & 1.39 & .95 & 2.9 & 110 \\
\hline $92 / 09 / 18$ & 0240 & $92 / 09 / 20$ & 0800 & 1.48 & 13 & 97 & 950 \\
\hline
\end{tabular}


Appendix 1. Storm-load data for rural watershed-management evaluation monitoring sites, Wisconsin, water years ${ }^{1}$ 1985-93-Continued

[yr, year; mo, month; d, day; $h$, hour; in., inches; $\mathrm{Mft}^{3}$, million cubic feet; lb, pounds; s/m, snowmelt; --, no data]

\begin{tabular}{|c|c|c|c|c|c|c|c|}
\hline \multicolumn{2}{|c|}{ Start of storm } & \multicolumn{2}{|c|}{ End of storm } & \multirow[b]{2}{*}{$\begin{array}{l}\text { Precipitation } \\
\text { (in.) }\end{array}$} & \multirow[b]{2}{*}{$\begin{array}{c}\text { Streamflow } \\
\text { volume } \\
\left(\mathrm{Mft}^{3}\right)\end{array}$} & \multicolumn{2}{|c|}{ Loads } \\
\hline $\begin{array}{c}\text { Date } \\
\text { (yr/mo/d) }\end{array}$ & $\begin{array}{l}\text { Time } \\
(24 \mathrm{~h})\end{array}$ & $\begin{array}{c}\text { Date } \\
(\mathrm{yr} / \mathrm{mo} / \mathrm{d})\end{array}$ & $\begin{array}{l}\text { Time } \\
(24 \mathrm{~h})\end{array}$ & & & $\begin{array}{l}\text { Suspended- } \\
\text { solids load } \\
\text { (tons) }\end{array}$ & $\begin{array}{c}\text { Total- } \\
\text { phosphorus } \\
\text { load } \\
\text { (lb) }\end{array}$ \\
\hline \multicolumn{8}{|c|}{ Bower Creek-Continued } \\
\hline $92 / 09 / 26$ & 1000 & $92 / 09 / 30$ & 0510 & 1.11 & 3.3 & 2.7 & 120 \\
\hline $92 / 11 / 01$ & 1900 & $92 / 11 / 03$ & 2300 & 1.27 & 8.1 & 40 & 550 \\
\hline $92 / 11 / 08$ & 2300 & $92 / 11 / 12$ & 0401 & .34 & 4.1 & 3.7 & 130 \\
\hline $92 / 11 / 12$ & 1200 & $92 / 11 / 14$ & 1001 & .34 & 4.7 & 6.3 & 170 \\
\hline $92 / 11 / 20$ & 0005 & $92 / 11 / 22$ & 0530 & 1.60 & 38 & 270 & 2,500 \\
\hline $92 / 12 / 15$ & 0715 & $92 / 12 / 17$ & 2216 & 1.02 & 47 & 180 & 1,900 \\
\hline $92 / 12 / 29$ & 0600 & $92 / 12 / 31$ & 2301 & $\mathrm{~s} / \mathrm{m}$ & 1.6 & .77 & 58 \\
\hline $93 / 03 / 02$ & 1140 & $93 / 03 / 18$ & 1801 & $\mathrm{~s} / \mathrm{m}$ & 29 & 30 & 1,600 \\
\hline $93 / 03 / 24$ & 0859 & $93 / 03 / 31$ & 1501 & $\mathrm{~s} / \mathrm{m}$ & 22 & 26 & 1,100 \\
\hline $93 / 04 / 04$ & 1130 & $93 / 04 / 07$ & 1101 & $\mathrm{~s} / \mathrm{m}$ & 9.5 & 22 & 350 \\
\hline $93 / 04 / 07$ & 1345 & $93 / 04 / 10$ & 0101 & .76 & 28 & 290 & 1,700 \\
\hline $93 / 04 / 11$ & 1459 & $93 / 04 / 14$ & 0801 & $\mathrm{~s} / \mathrm{m}$ & 7.4 & 8.0 & 230 \\
\hline $93 / 04 / 15$ & 0559 & $93 / 04 / 19$ & 0301 & 1.01 & 46 & 420 & 2,400 \\
\hline $93 / 04 / 19$ & 0900 & $93 / 04 / 23$ & 0801 & .49 & 32 & 140 & 1,300 \\
\hline $93 / 04 / 27$ & 1729 & $93 / 04 / 29$ & 1401 & .55 & 8.5 & 27 & 340 \\
\hline $93 / 05 / 30$ & 1245 & $93 / 06 / 03$ & 0531 & .92 & 4.0 & 2.5 & 110 \\
\hline $93 / 06 / 08$ & 0300 & $93 / 06 / 11$ & 1201 & 2.51 & 38 & 1,100 & 3,600 \\
\hline $93 / 06 / 14$ & 0225 & $93 / 06 / 16$ & 0021 & .96 & 6.9 & 110 & 480 \\
\hline $93 / 08 / 05$ & 2300 & $93 / 08 / 08$ & 1700 & 1.18 & 1.6 & 5.1 & -- \\
\hline $93 / 10 / 15$ & 1730 & $93 / 10 / 19$ & 0300 & - & 1.8 & 1.4 & 19 \\
\hline $93 / 10 / 20$ & 2200 & $93 / 10 / 23$ & 2200 & -- & 2.2 & 1.5 & 78 \\
\hline $93 / 11 / 12$ & 2200 & $93 / 11 / 18$ & 0600 & -- & 3.2 & 1.2 & 68 \\
\hline $93 / 11 / 26$ & 0700 & $93 / 11 / 29$ & 0900 & -- & 2.9 & 3.6 & 89 \\
\hline $94 / 02 / 19$ & 0700 & $94 / 02 / 25$ & 0300 & -- & 78 & 46 & 930 \\
\hline $94 / 03 / 04$ & 1200 & $94 / 03 / 09$ & 2200 & -- & 36 & 48 & 770 \\
\hline $94 / 04 / 12$ & 1500 & $94 / 04 / 14$ & 1000 & -- & 3.3 & 7.3 & 65 \\
\hline $94 / 04 / 15$ & 0245 & $94 / 04 / 17$ & 0900 & -- & 5.9 & 37 & 230 \\
\hline $94 / 04 / 24$ & 2000 & $94 / 04 / 27$ & 0345 & -- & 45 & 2,200 & 6,000 \\
\hline $94 / 07 / 04$ & 0100 & $94 / 07 / 09$ & 2100 & -- & 3.2 & 6.6 & 100 \\
\hline \multicolumn{8}{|c|}{ Otter Creek } \\
\hline $90 / 09 / 06$ & 1940 & $90 / 09 / 08$ & 1845 & 1.53 & 1.5 & 7.1 & 63 \\
\hline $90 / 09 / 14$ & 0540 & $90 / 09 / 18$ & 2335 & 1.67 & 6.5 & 26 & 190 \\
\hline $90 / 11 / 05$ & 0610 & $90 / 11 / 06$ & 1030 & .79 & 1.2 & 1.2 & 20 \\
\hline $91 / 02 / 03$ & 0300 & $91 / 02 / 08$ & 1400 & $\mathrm{~s} / \mathrm{m}$ & 10 & 11 & 180 \\
\hline $91 / 03 / 01$ & 1100 & $91 / 03 / 04$ & 1600 & $\mathrm{~s} / \mathrm{m}$ & 5.3 & 27 & -- \\
\hline $91 / 06 / 14$ & 1735 & $91 / 06 / 18$ & 0300 & 2.24 & 5.2 & 35 & 230 \\
\hline $91 / 10 / 24$ & 1200 & $91 / 10 / 26$ & 1245 & 1.85 & 2.0 & 8.3 & 57 \\
\hline
\end{tabular}


Appendix 1. Storm-load data for rural watershed-management evaluation monitoring sites, Wisconsin, water years ${ }^{1}$ 1985-93-Continued

[yr, year; mo, month; d, day; h, hour; in., inches; $\mathrm{Mft}^{3}$, million cubic feet; lb, pounds; $\mathrm{s} / \mathrm{m}$, snowmelt; --, no data]

\begin{tabular}{|c|c|c|c|c|c|c|c|}
\hline \multicolumn{2}{|c|}{ Start of storm } & \multicolumn{2}{|c|}{ End of storm } & \multirow[b]{2}{*}{$\begin{array}{c}\text { Precipitation } \\
\text { (in.) }\end{array}$} & \multirow[b]{2}{*}{$\begin{array}{c}\text { Streamflow } \\
\text { volume } \\
\left(\mathrm{Mft}^{3}\right)\end{array}$} & \multicolumn{2}{|c|}{ Loads } \\
\hline $\begin{array}{c}\text { Date } \\
\text { (yr/mo/d) }\end{array}$ & $\begin{array}{l}\text { Time } \\
(24 h)\end{array}$ & $\begin{array}{c}\text { Date } \\
(y r / m o / d)\end{array}$ & $\begin{array}{l}\text { Time } \\
(24 h)\end{array}$ & & & $\begin{array}{l}\text { Suspended- } \\
\text { solids load } \\
\text { (tons) }\end{array}$ & $\begin{array}{c}\text { Total- } \\
\text { phosphorus } \\
\text { load } \\
\text { (lb) }\end{array}$ \\
\hline \multicolumn{8}{|c|}{ Otter Creek-Continued } \\
\hline $91 / 10 / 26$ & 1245 & $91 / 10 / 27$ & 2300 & .46 & 1.4 & 1.6 & 23 \\
\hline $91 / 10 / 29$ & 0225 & $91 / 10 / 30$ & 1910 & -- & 2.6 & 11 & 83 \\
\hline $91 / 11 / 01$ & 1200 & $91 / 11 / 03$ & 0005 & .53 & 2.2 & 8.1 & 70 \\
\hline $91 / 11 / 14$ & 1535 & $91 / 11 / 17$ & 0155 & .46 & 2.0 & 3.0 & 24 \\
\hline $91 / 11 / 18$ & 0140 & $91 / 11 / 20$ & 1810 & .39 & 2.7 & 7.6 & 45 \\
\hline $91 / 11 / 29$ & 2015 & $91 / 12 / 02$ & 2235 & 1.38 & 6.7 & 19 & 150 \\
\hline $92 / 02 / 27$ & 1200 & $92 / 03 / 01$ & 0900 & $\mathrm{~s} / \mathrm{m}$ & 4.1 & 12 & 110 \\
\hline $92 / 03 / 01$ & 0900 & $92 / 03 / 03$ & 0900 & $\mathrm{~s} / \mathrm{m}$ & 4.1 & 14 & 130 \\
\hline $92 / 03 / 05$ & 2100 & $92 / 03 / 08$ & 1100 & .37 & 5.8 & 15 & 100 \\
\hline $92 / 03 / 09$ & 0335 & $92 / 03 / 10$ & 1930 & .55 & 4.8 & 24 & 98 \\
\hline $92 / 03 / 24$ & 1200 & $92 / 03 / 28$ & 0700 & $\mathrm{~s} / \mathrm{m}$ & 6.0 & 8.3 & 82 \\
\hline $92 / 04 / 10$ & 1800 & $92 / 04 / 13$ & 0500 & .81 & 4.1 & 19 & 82 \\
\hline $92 / 04 / 16$ & 0500 & $92 / 04 / 18$ & 0540 & .80 & 4.5 & 25 & 110 \\
\hline $92 / 09 / 14$ & 1230 & $92 / 09 / 15$ & 0600 & 1.01 & .24 & .27 & 2.8 \\
\hline $92 / 09 / 16$ & 0950 & $92 / 09 / 17$ & 0640 & 1.00 & .41 & 1.1 & 13 \\
\hline $92 / 09 / 18$ & 0440 & $92 / 09 / 19$ & 0735 & 1.09 & .82 & 3.1 & 25 \\
\hline $92 / 09 / 26$ & 2110 & $92 / 09 / 28$ & 1700 & .74 & .63 & .52 & 5.2 \\
\hline $92 / 11 / 01$ & 1600 & $92 / 11 / 03$ & 1600 & 1.55 & 2.4 & 6.5 & 57 \\
\hline $92 / 11 / 12$ & 0800 & $92 / 11 / 13$ & 1901 & .39 & .92 & .62 & 9.3 \\
\hline $92 / 11 / 19$ & 2300 & $92 / 11 / 22$ & 1701 & .84 & 4.2 & 16 & 120 \\
\hline $92 / 11 / 25$ & 1900 & $92 / 11 / 27$ & 1901 & .35 & 2.7 & 3.0 & 53 \\
\hline $92 / 12 / 15$ & 0520 & $92 / 12 / 17$ & 1301 & .97 & 7.6 & 32 & 220 \\
\hline $92 / 12 / 29$ & 0744 & $92 / 12 / 30$ & 0731 & .30 & .83 & .44 & 7.8 \\
\hline $93 / 03 / 24$ & 1050 & $93 / 04 / 01$ & 1201 & $\mathrm{~s} / \mathrm{m}$ & 29 & 39 & 450 \\
\hline $93 / 04 / 03$ & 1400 & $93 / 04 / 06$ & 0900 & $\mathrm{~s} / \mathrm{m}$ & 5.7 & 4.8 & 58 \\
\hline $93 / 04 / 08$ & 0035 & $93 / 04 / 09$ & 1833 & 1.10 & 12 & 45 & 270 \\
\hline $93 / 04 / 11$ & 1100 & $93 / 04 / 13$ & 1001 & .45 & 6.4 & 5.3 & 69 \\
\hline $93 / 04 / 15$ & 0335 & $93 / 04 / 17$ & 0713 & 1.43 & 18 & 74 & 420 \\
\hline $93 / 04 / 19$ & 1505 & $93 / 04 / 21$ & 2152 & 1.50 & 20 & 67 & 440 \\
\hline $93 / 06 / 07$ & 1230 & $93 / 06 / 09$ & 2045 & 2.39 & 14 & 140 & 510 \\
\hline $93 / 07 / 05$ & 1700 & $93 / 07 / 07$ & 2100 & 2.04 & 12 & 160 & 580 \\
\hline $93 / 07 / 09$ & 0300 & $93 / 07 / 10$ & 2200 & 1.42 & 8.0 & 120 & 410 \\
\hline $93 / 09 / 13$ & 1045 & $93 / 09 / 16$ & 0700 & 2.34 & 2.3 & 3.7 & 37 \\
\hline $93 / 09 / 20$ & 1435 & $93 / 09 / 22$ & 0900 & 1.49 & 2.6 & 12 & 78 \\
\hline $93 / 12 / 24$ & 2100 & $94 / 01 / 04$ & 0500 & -- & 18 & .0034 & .039 \\
\hline $94 / 03 / 20$ & 1200 & $94 / 03 / 25$ & 0800 & -- & 10 & 9 & 85 \\
\hline $94 / 04 / 24$ & 2200 & $94 / 04 / 27$ & 0800 & -- & 4.1 & 9.9 & 70 \\
\hline
\end{tabular}


Appendix 1. Storm-load data for rural watershed-management evaluation monitoring sites, Wisconsin, water years ${ }^{1}$ 1985-93-Continued

[yr, year; mo, month; d, day; $\mathbf{h}$, hour; in., inches; $\mathrm{Mft}^{3}$, million cubic feet; lb, pounds; s/m, snowmelt; --, no data]

\begin{tabular}{|c|c|c|c|c|c|c|c|}
\hline \multicolumn{2}{|c|}{ Start of storm } & \multicolumn{2}{|c|}{ End of storm } & \multirow[b]{2}{*}{$\begin{array}{l}\text { Precipitation } \\
\text { (in.) }\end{array}$} & \multirow[b]{2}{*}{$\begin{array}{l}\text { Streamflow } \\
\text { volume } \\
\left(\mathrm{Mft}^{3}\right)\end{array}$} & \multicolumn{2}{|c|}{ Loads } \\
\hline $\begin{array}{c}\text { Date } \\
\text { (yr/mo/d) }\end{array}$ & $\begin{array}{l}\text { Time } \\
(24 \mathrm{~h})\end{array}$ & $\begin{array}{c}\text { Date } \\
(\mathrm{yr} / \mathrm{mo} / \mathrm{d})\end{array}$ & $\begin{array}{l}\text { Time } \\
(24 h)\end{array}$ & & & $\begin{array}{l}\text { Suspended- } \\
\text { solids load } \\
\text { (tons) }\end{array}$ & $\begin{array}{c}\text { Total- } \\
\text { phosphorus } \\
\text { load } \\
\text { (lb) }\end{array}$ \\
\hline \multicolumn{8}{|c|}{ Otter Creek-Continued } \\
\hline $94 / 05 / 25$ & 1900 & $94 / 05 / 27$ & 2200 & -- & 2.2 & 34 & 130 \\
\hline $94 / 08 / 01$ & 0200 & $94 / 08 / 02$ & 2100 & -- & .82 & .52 & 8.2 \\
\hline \multicolumn{8}{|c|}{ Kuenster Creek } \\
\hline $92 / 11 / 01$ & 1900 & $92 / 11 / 04$ & 0100 & 1.38 & 1.0 & 1.8 & 36 \\
\hline $92 / 11 / 19$ & 1600 & $92 / 11 / 22$ & 0100 & 2.73 & 2.4 & 19 & 300 \\
\hline $92 / 12 / 15$ & 0200 & $92 / 12 / 17$ & 0400 & $\mathrm{~s} / \mathrm{m}$ & 1.7 & 8.2 & 220 \\
\hline $93 / 03 / 05$ & 1100 & $93 / 03 / 06$ & 0400 & $\mathrm{~s} / \mathrm{m}$ & 1.7 & 85 & 440 \\
\hline $93 / 03 / 07$ & 1400 & $93 / 03 / 08$ & 0700 & $\mathrm{~s} / \mathrm{m}$ & 4.2 & 2.70 & 1,200 \\
\hline $93 / 03 / 08$ & 1400 & $93 / 03 / 09$ & 0800 & $\mathrm{~s} / \mathrm{m}$ & 3.4 & 83 & 560 \\
\hline $93 / 03 / 15$ & 2300 & $93 / 03 / 17$ & 0900 & $\mathrm{~s} / \mathrm{m}$ & 6.5 & 290 & 920 \\
\hline $93 / 03 / 25$ & 1200 & $93 / 03 / 26$ & 0900 & $\mathrm{~s} / \mathrm{m}$ & 9.7 & 1,100 & 3,600 \\
\hline $93 / 03 / 26$ & 1200 & $93 / 03 / 27$ & 0700 & $\mathrm{~s} / \mathrm{m}$ & 7.8 & 430 & 1,400 \\
\hline $93 / 03 / 27$ & 1200 & $93 / 03 / 28$ & 0500 & $\mathrm{~s} / \mathrm{m}$ & 6.6 & 210 & 1,190 \\
\hline $93 / 03 / 28$ & 1300 & $93 / 03 / 29$ & 0600 & $\mathrm{~s} / \mathrm{m}$ & 4.1 & 91 & 540 \\
\hline $93 / 03 / 30$ & 1200 & $93 / 03 / 31$ & 1900 & 1.78 & 14 & 3,000 & 6,700 \\
\hline $93 / 05 / 02$ & 1900 & $93 / 05 / 03$ & 1000 & 1.63 & 3.8 & 340 & 1,400 \\
\hline $93 / 06 / 17$ & 1800 & $93 / 06 / 18$ & 2000 & .72 & 3.4 & 100 & 730 \\
\hline $93 / 06 / 28$ & 1600 & $93 / 06 / 29$ & 0600 & -- & 1.4 & 20 & 80 \\
\hline $93 / 06 / 29$ & 2300 & $93 / 06 / 30$ & 2200 & 1.42 & 5.8 & 470 & 1,600 \\
\hline $93 / 07 / 17$ & 1000 & $93 / 07 / 17$ & 1900 & 1.07 & 2.2 & 170 & 470 \\
\hline $93 / 08 / 14$ & 1715 & $93 / 08 / 16$ & 0500 & 1.00 & 4.4 & 120 & 455 \\
\hline $93 / 08 / 18$ & 1100 & $93 / 08 / 19$ & 1100 & .88 & 2.4 & 36 & 190 \\
\hline $94 / 03 / 04$ & 1200 & $94 / 03 / 05$ & 0800 & -- & 6 & 790 & 2,000 \\
\hline $94 / 03 / 05$ & 1200 & $94 / 03 / 06$ & 1100 & -- & 3 & 85 & 330 \\
\hline $94 / 06 / 20$ & 0200 & $94 / 06 / 20$ & 1300 & -- & .47 & 6.6 & 49 \\
\hline $94 / 06 / 23$ & 0600 & $94 / 06 / 24$ & 2200 & -- & 4.9 & 130 & 490 \\
\hline $94 / 07 / 04$ & 0800 & $94 / 07 / 05$ & 1900 & -- & 2.4 & 95 & 390 \\
\hline $94 / 07 / 14$ & 0100 & $94 / 07 / 15$ & 0300 & -- & 2.9 & 190 & 140 \\
\hline $94 / 07 / 20$ & 0000 & $94 / 07 / 21$ & 0200 & -- & 2.1 & 55 & 230 \\
\hline \multicolumn{8}{|c|}{ Rattlesnake Creek } \\
\hline $90 / 01 / 16$ & 1700 & $90 / 01 / 18$ & 0800 & $\mathrm{~s} / \mathrm{m}$ & 9.4 & 150 & 1,600 \\
\hline $90 / 03 / 08$ & 0600 & $90 / 03 / 08$ & 1200 & $\mathrm{~s} / \mathrm{m}$ & 16 & 1,300 & 3,600 \\
\hline $90 / 03 / 11$ & 0500 & $90 / 03 / 12$ & 0200 & $\mathrm{~s} / \mathrm{m}$ & 4.1 & 57 & 480 \\
\hline $90 / 05 / 09$ & 0115 & $90 / 05 / 10$ & 0100 & -- & 3.2 & 170 & 360 \\
\hline $90 / 05 / 19$ & 0500 & $90 / 05 / 20$ & 2100 & -. & 5.8 & 83 & 530 \\
\hline $90 / 06 / 22$ & 0315 & $90 / 06 / 22$ & 1800 & -- & 3.3 & 55 & 180 \\
\hline
\end{tabular}


Appendix 1. Storm-load data for rural watershed-management evaluation monitoring sites, Wisconsin, water years ${ }^{1}$ 1985-93-Continued

[yr, year; mo, month; d, day; $h$, hour; in., inches; $\mathrm{Mft}^{3}$, million cubic feet; lb, pounds; s/m, snowmelt; --, no data]

\begin{tabular}{|c|c|c|c|c|c|c|c|}
\hline \multicolumn{2}{|c|}{ Start of storm } & \multicolumn{2}{|c|}{ End of storm } & \multirow[b]{2}{*}{$\begin{array}{l}\text { Precipitation } \\
\text { (in.) }\end{array}$} & \multirow[b]{2}{*}{$\begin{array}{c}\text { Streamflow } \\
\text { volume } \\
\left(\mathrm{Mft}^{3}\right)\end{array}$} & \multicolumn{2}{|c|}{ Loads } \\
\hline $\begin{array}{c}\text { Date } \\
\text { (yr/mo/d) }\end{array}$ & $\begin{array}{l}\text { Time } \\
(24 \mathrm{~h})\end{array}$ & $\begin{array}{c}\text { Date } \\
\text { (yr/mo/d) }\end{array}$ & $\begin{array}{l}\text { Time } \\
(24 \mathrm{~h})\end{array}$ & & & $\begin{array}{l}\text { Suspended- } \\
\text { solids load } \\
\text { (tons) }\end{array}$ & $\begin{array}{c}\text { Total- } \\
\text { phosphorus } \\
\text { load } \\
\text { (lb) }\end{array}$ \\
\hline \multicolumn{8}{|c|}{ Rattlesnake Creek-Continued } \\
\hline $90 / 08 / 24$ & 2000 & $90 / 08 / 25$ & 2300 & -- & 7.9 & 230 & 1,600 \\
\hline $90 / 08 / 26$ & 0900 & $90 / 08 / 27$ & 0400 & -- & 5.6 & 190 & 940 \\
\hline $91 / 04 / 12$ & 1100 & $91 / 04 / 13$ & 1900 & 1.64 & 14 & 98 & 1,000 \\
\hline $91 / 08 / 07$ & 2000 & $91 / 08 / 08$ & 2300 & 2.50 & 8.3 & 200 & 4,600 \\
\hline $91 / 11 / 01$ & 0045 & $91 / 11 / 02$ & 0330 & 1.55 & 5.9 & 59 & 650 \\
\hline $91 / 11 / 29$ & 1100 & $91 / 11 / 30$ & 1700 & .80 & 6.2 & 29 & 230 \\
\hline $92 / 02 / 03$ & 1300 & $92 / 02 / 04$ & 0900 & $\mathrm{~s} / \mathrm{m}$ & 3.7 & 69 & 290 \\
\hline $92 / 02 / 20$ & 1445 & $92 / 02 / 21$ & 0800 & $\mathrm{~s} / \mathrm{m}$ & 19 & 2,800 & 7,600 \\
\hline $92 / 02 / 22$ & 1400 & $92 / 02 / 23$ & 1635 & $\mathrm{~s} / \mathrm{m}$ & 14 & 1,600 & 4,400 \\
\hline $92 / 02 / 24$ & 1500 & $92 / 02 / 25$ & 0900 & .24 & 8.6 & 420 & 1,700 \\
\hline $92 / 04 / 20$ & 1300 & $92 / 04 / 21$ & 0900 & .91 & 4.4 & 34 & 520 \\
\hline $92 / 06 / 16$ & 1000 & $92 / 06 / 17$ & 0300 & .66 & 1.3 & .44 & 14 \\
\hline $92 / 09 / 07$ & 2230 & $92 / 09 / 08$ & 1800 & .90 & 2.3 & 4.1 & 180 \\
\hline $92 / 09 / 14$ & 1400 & $92 / 09 / 15$ & 1800 & .84 & 2.3 & 2.9 & 130 \\
\hline $92 / 11 / 01$ & 1600 & $92 / 11 / 03$ & 1000 & 1.25 & 3.7 & 3.3 & 64 \\
\hline $92 / 11 / 19$ & 2000 & $92 / 11 / 21$ & 2200 & 2.68 & 10 & 68 & 1,300 \\
\hline $92 / 12 / 15$ & 0100 & $92 / 12 / 17$ & 0400 & .91 & 7.6 & 27 & 510 \\
\hline $93 / 03 / 03$ & 0300 & $93 / 03 / 05$ & 0600 & .27 & 16 & 2,100 & 4,000 \\
\hline $93 / 03 / 05$ & 1400 & $93 / 03 / 06$ & 0800 & $\mathrm{~s} / \mathrm{m}$ & 7.7 & 330 & 1,700 \\
\hline $93 / 03 / 06$ & 1500 & $93 / 03 / 07$ & 0800 & $\mathrm{~s} / \mathrm{m}$ & 4.8 & 120 & 1,500 \\
\hline $93 / 03 / 07$ & 1400 & $93 / 03 / 08$ & 1000 & $\mathrm{~s} / \mathrm{m}$ & 19 & 610 & 4,700 \\
\hline $93 / 03 / 08$ & 1300 & $93 / 03 / 09$ & 0900 & $\mathrm{~s} / \mathrm{m}$ & 18 & 380 & 3,600 \\
\hline $93 / 03 / 16$ & 0030 & $93 / 03 / 17$ & 0600 & $\mathrm{~s} / \mathrm{m}$ & 31 & 1,400 & 4,200 \\
\hline $93 / 03 / 24$ & 1600 & $93 / 03 / 26$ & 1100 & $\mathrm{~s} / \mathrm{m}$ & 63 & 4,300 & 14,000 \\
\hline $93 / 03 / 26$ & 1101 & $93 / 03 / 27$ & 1000 & $\mathrm{~s} / \mathrm{m}$ & 31 & 420 & 3,000 \\
\hline $93 / 03 / 27$ & 1200 & $93 / 03 / 28$ & 0800 & $\mathrm{~s} / \mathrm{m}$ & 26 & 840 & 4,300 \\
\hline $93 / 03 / 28$ & 1300 & $93 / 03 / 29$ & 0900 & $\mathrm{~s} / \mathrm{m}$ & 15 & 240 & 1,700 \\
\hline $93 / 03 / 30$ & 1300 & $93 / 03 / 31$ & 2000 & 1.67 & 43 & 4,400 & 14,000 \\
\hline $93 / 05 / 02$ & 2100 & $93 / 05 / 03$ & 1500 & 1.64 & 17 & 500 & 2,600 \\
\hline $93 / 06 / 07$ & 1000 & $93 / 06 / 08$ & 1900 & 1.53 & 13 & 260 & 1,100 \\
\hline $93 / 06 / 13$ & 2100 & $93 / 06 / 14$ & 2100 & 1.01 & 5.0 & 29 & 170 \\
\hline $93 / 06 / 17$ & 1900 & $93 / 06 / 18$ & 1500 & 1.25 & 13 & 690 & 2,700 \\
\hline $93 / 06 / 28$ & 0600 & $93 / 06 / 28$ & 1500 & .71 & 4.7 & 160 & 570 \\
\hline $93 / 06 / 29$ & 2300 & $93 / 06 / 30$ & 1800 & 1.36 & 19 & 1,300 & 4,400 \\
\hline $93 / 07 / 05$ & 1200 & 93/07/06 & 1500 & 1.69 & 19 & 470 & 3,000 \\
\hline $93 / 07 / 08$ & 2330 & $93 / 07 / 09$ & 2000 & 2.35 & 71 & 8,700 & 25,000 \\
\hline $93 / 07 / 10$ & 1600 & $93 / 07 / 12$ & 0400 & 2.39 & 78 & 8,500 & 24,000 \\
\hline
\end{tabular}


Appendix 1. Storm-load data for rural watershed-management evaluation monitoring sites, Wisconsin, water years ${ }^{1}$ 1985-93-Continued

[yr, year; mo, month; d, day; $h$, hour; in., inches; $\mathrm{Mft}^{3}$, million cubic feet; lb, pounds; $\mathrm{s} / \mathrm{m}$, snowmelt; --, no data]

\begin{tabular}{|c|c|c|c|c|c|c|c|}
\hline \multicolumn{2}{|c|}{ Start of storm } & \multicolumn{2}{|c|}{ End of storm } & \multirow[b]{2}{*}{$\begin{array}{l}\text { Precipitation } \\
\quad \text { (in.) }\end{array}$} & \multirow[b]{2}{*}{$\begin{array}{l}\text { Streamflow } \\
\text { volume } \\
\left(\mathrm{Mft}^{3}\right)\end{array}$} & \multicolumn{2}{|c|}{ Loads } \\
\hline $\begin{array}{c}\text { Date } \\
(\mathrm{yr} / \mathrm{mo} / \mathrm{d})\end{array}$ & $\begin{array}{l}\text { Time } \\
(24 \mathrm{~h})\end{array}$ & $\begin{array}{c}\text { Date } \\
(\mathrm{yr} / \mathrm{mo} / \mathrm{d})\end{array}$ & $\begin{array}{l}\text { Time } \\
(24 \mathrm{~h})\end{array}$ & & & $\begin{array}{l}\text { Suspended- } \\
\text { solids load } \\
\text { (tons) }\end{array}$ & $\begin{array}{l}\text { Total- } \\
\text { phosphorus } \\
\text { load } \\
\text { (lb) }\end{array}$ \\
\hline \multicolumn{8}{|c|}{ Rattlesnake Creek-Continued } \\
\hline $93 / 07 / 17$ & 0900 & $93 / 07 / 18$ & 0200 & 0.97 & 12 & 480 & 1,700 \\
\hline $93 / 08 / 14$ & 1700 & $93 / 08 / 15$ & 0545 & .97 & 6.5 & 130 & 590 \\
\hline $93 / 08 / 15$ & 0900 & $93 / 08 / 16$ & 0100 & .74 & 10 & 150 & 810 \\
\hline $93 / 08 / 18$ & 1300 & $93 / 08 / 19$ & 0600 & 1.00 & 11 & 220 & 1,200 \\
\hline $94 / 02 / 18$ & 1600 & $94 / 02 / 21$ & 0800 & -- & 160 & 4200 & 15000 \\
\hline $94 / 03 / 04$ & 1300 & $94 / 03 / 05$ & 0900 & -- & 27 & 1900 & 6300 \\
\hline $94 / 03 / 05$ & 1100 & $94 / 03 / 06$ & 0900 & -- & 13 & 290 & 1600 \\
\hline $94 / 06 / 20$ & 0100 & $94 / 06 / 20$ & 1900 & -- & 2.7 & 20 & 83 \\
\hline $94 / 06 / 23$ & 0700 & $94 / 06 / 24$ & 2300 & -- & 16 & 520 & 2200 \\
\hline $94 / 07 / 04$ & 0700 & $94 / 07 / 05$ & 1800 & -- & 7.8 & 170 & 870 \\
\hline $94 / 07 / 14$ & 0200 & $94 / 07 / 14$ & 2000 & -- & 6.4 & 320 & 280 \\
\hline $94 / 07 / 20$ & 0015 & $94 / 07 / 20$ & 1700 & -- & 5.5 & 140 & 730 \\
\hline
\end{tabular}

${ }^{1}$ Water year is the 12-month period, October 1 through September 30 . The water year is designated by the calendar year in which it ends. Thus, the year starting October 1, 1992, and ending September 30, 1993, is called "water year 1993." 


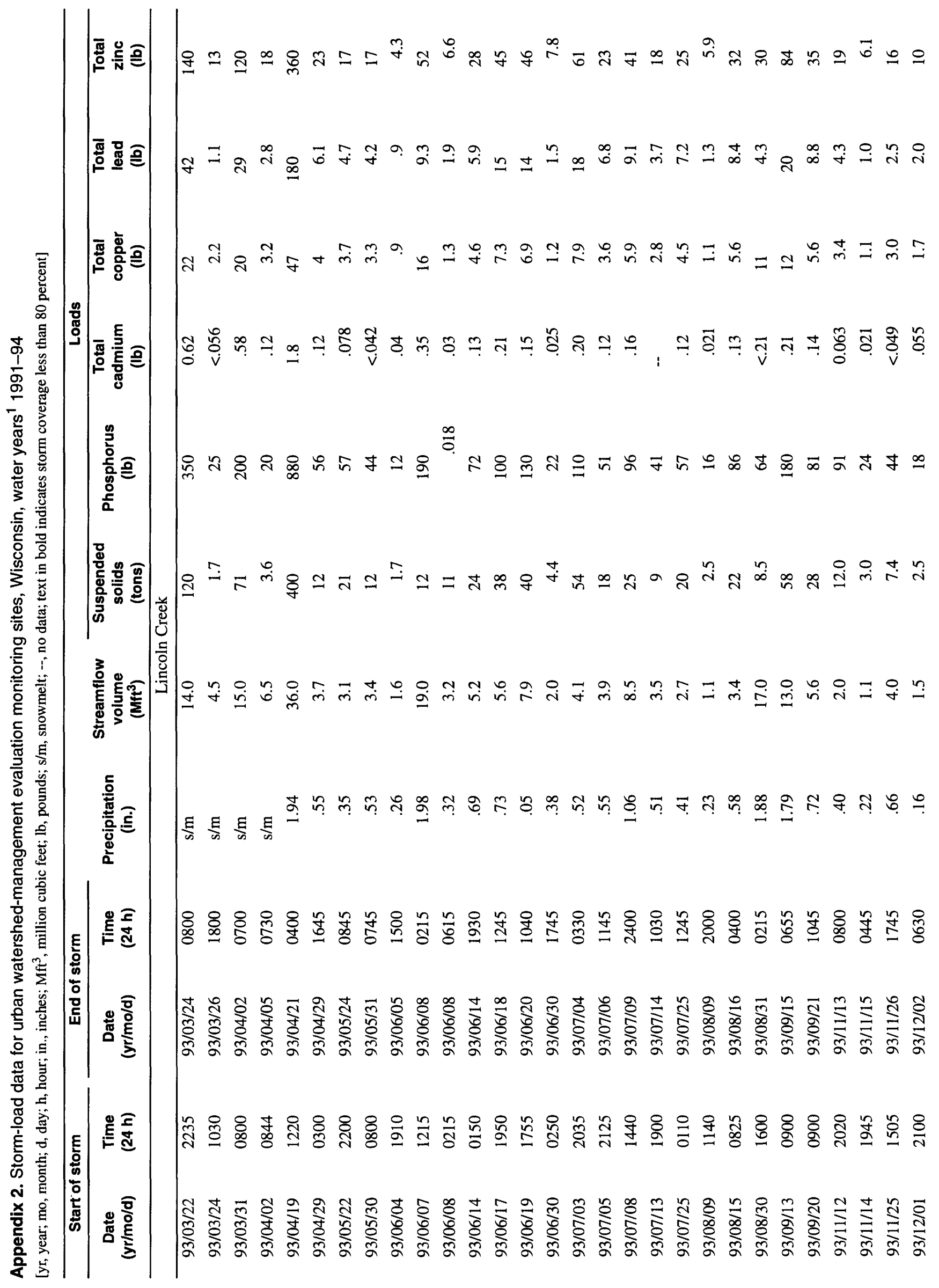




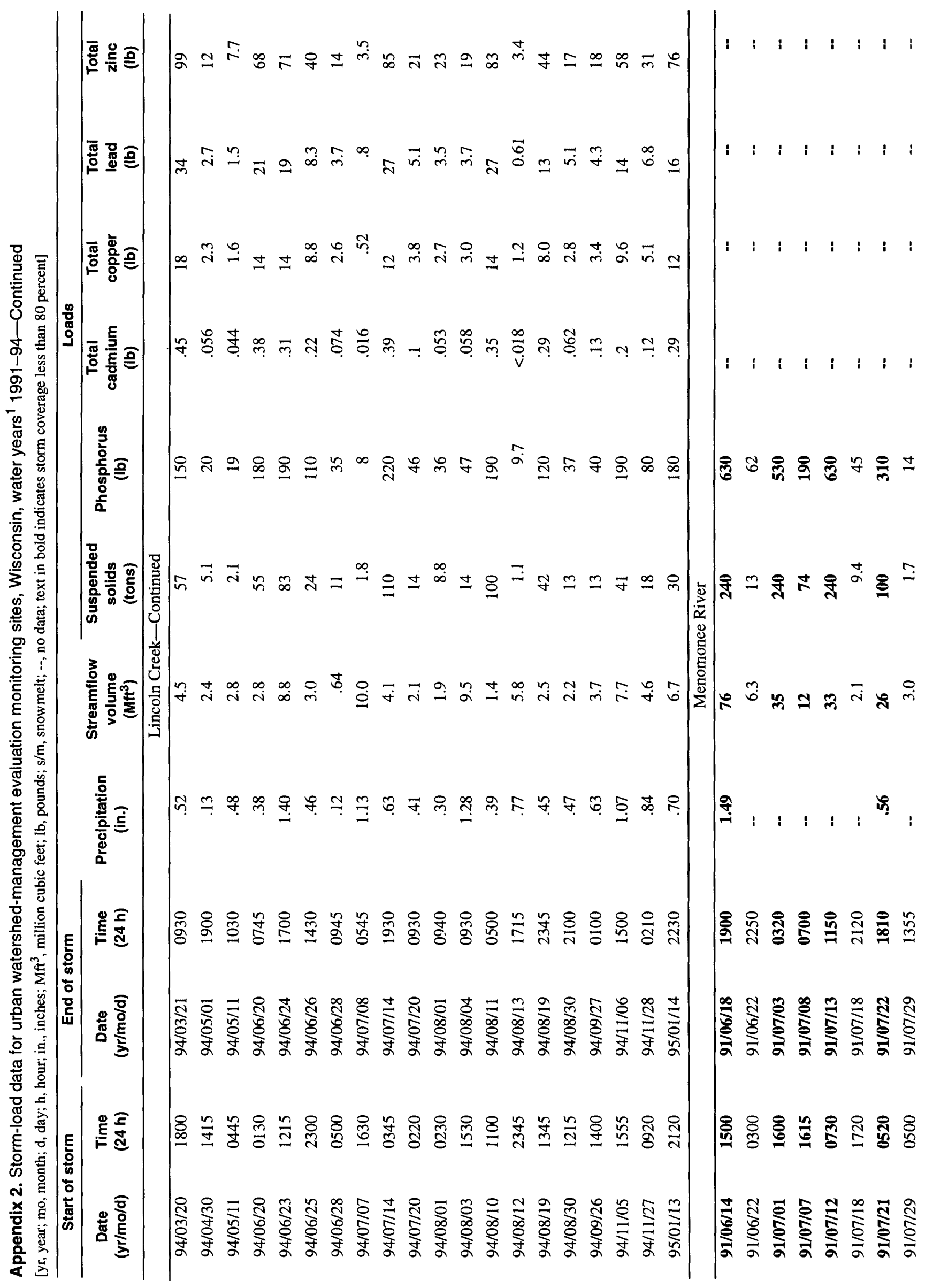




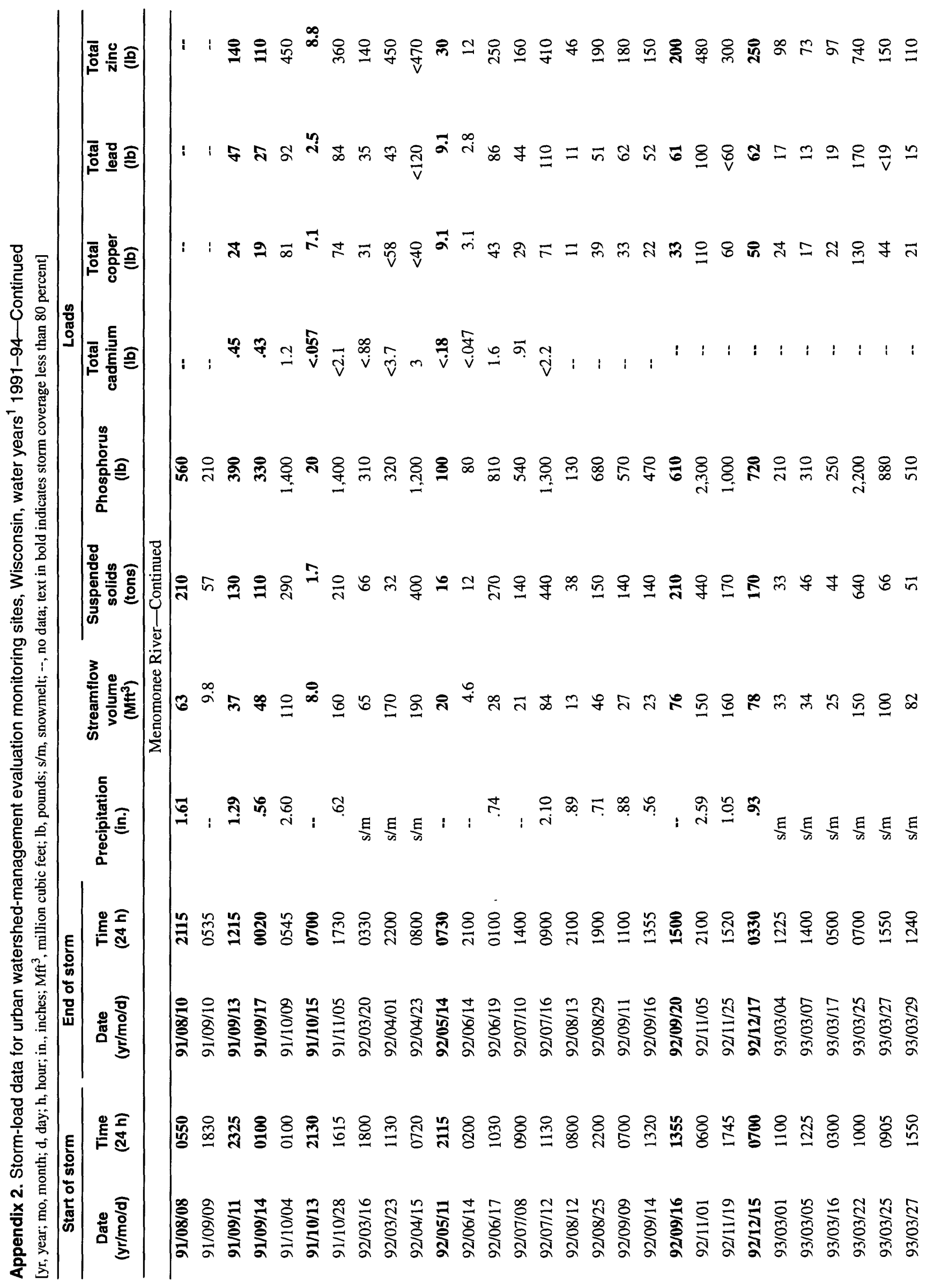




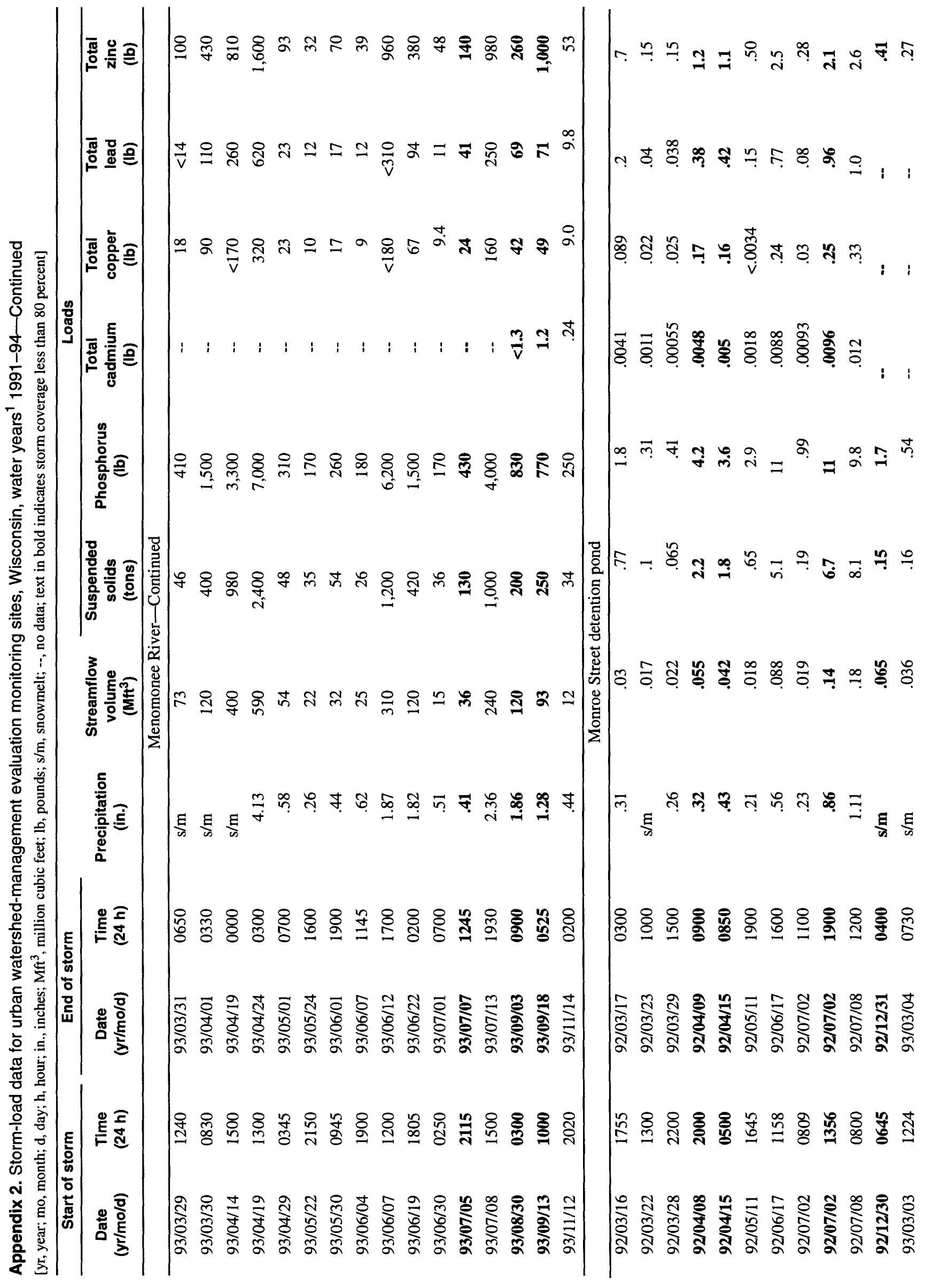




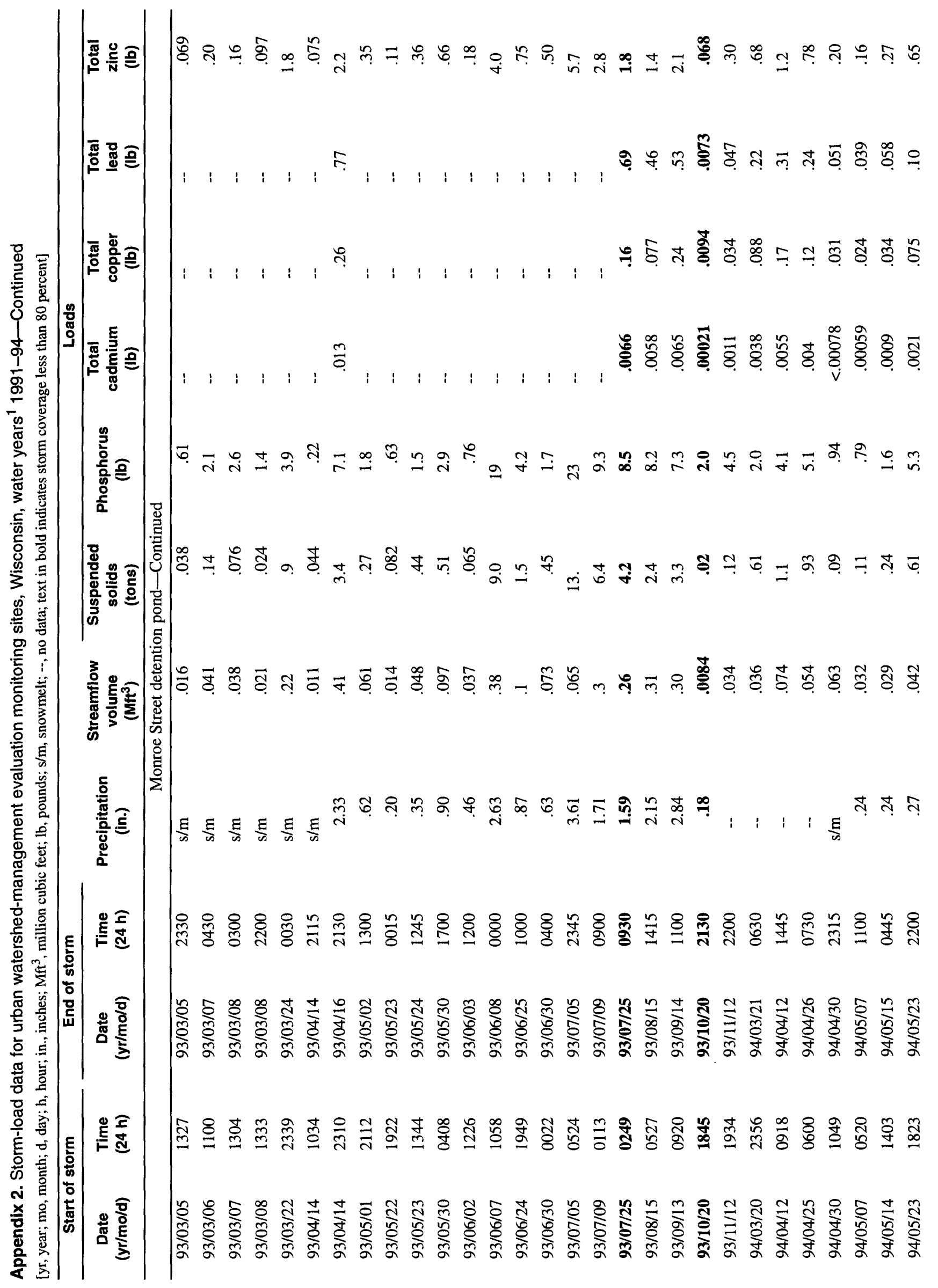




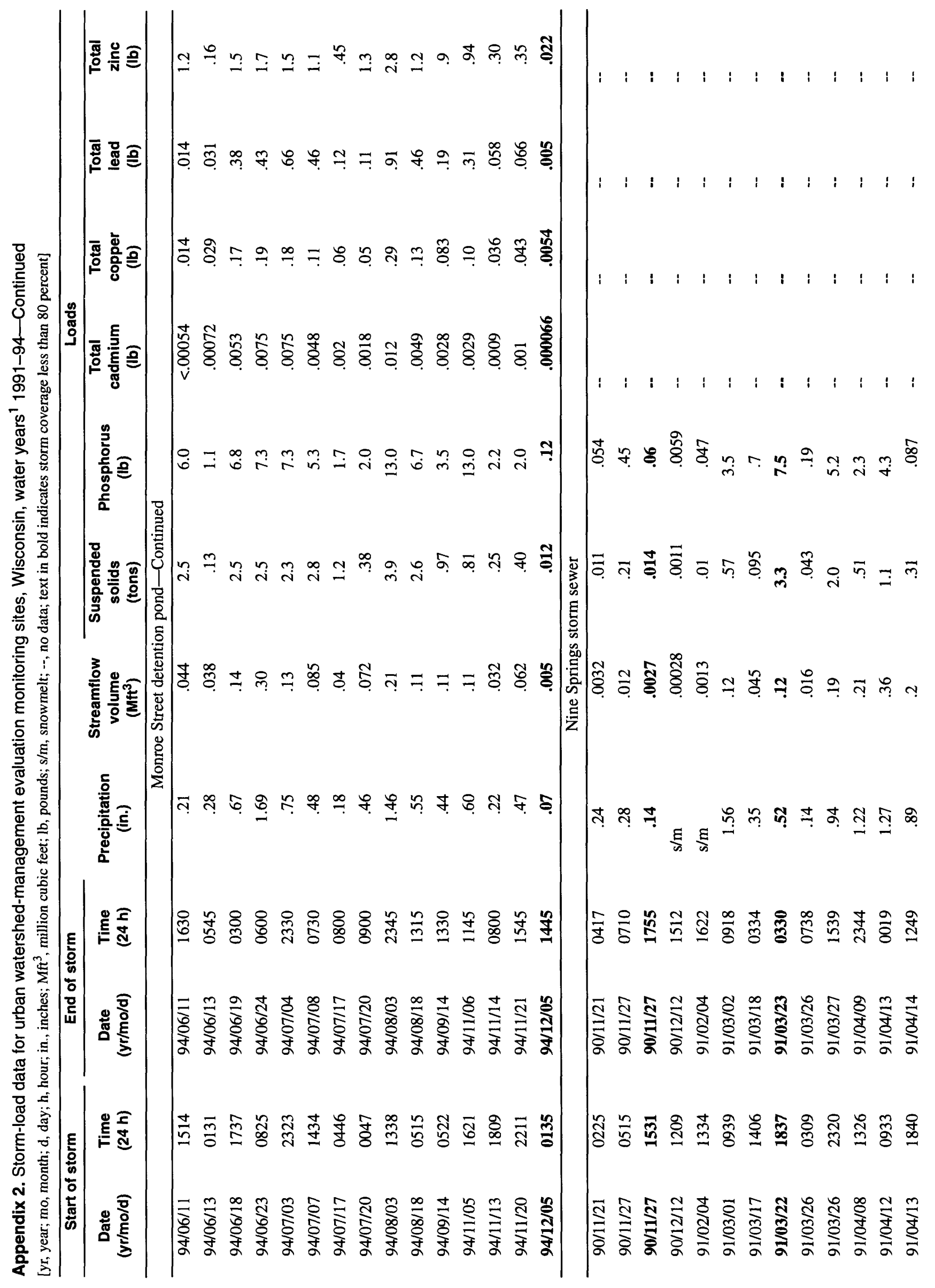




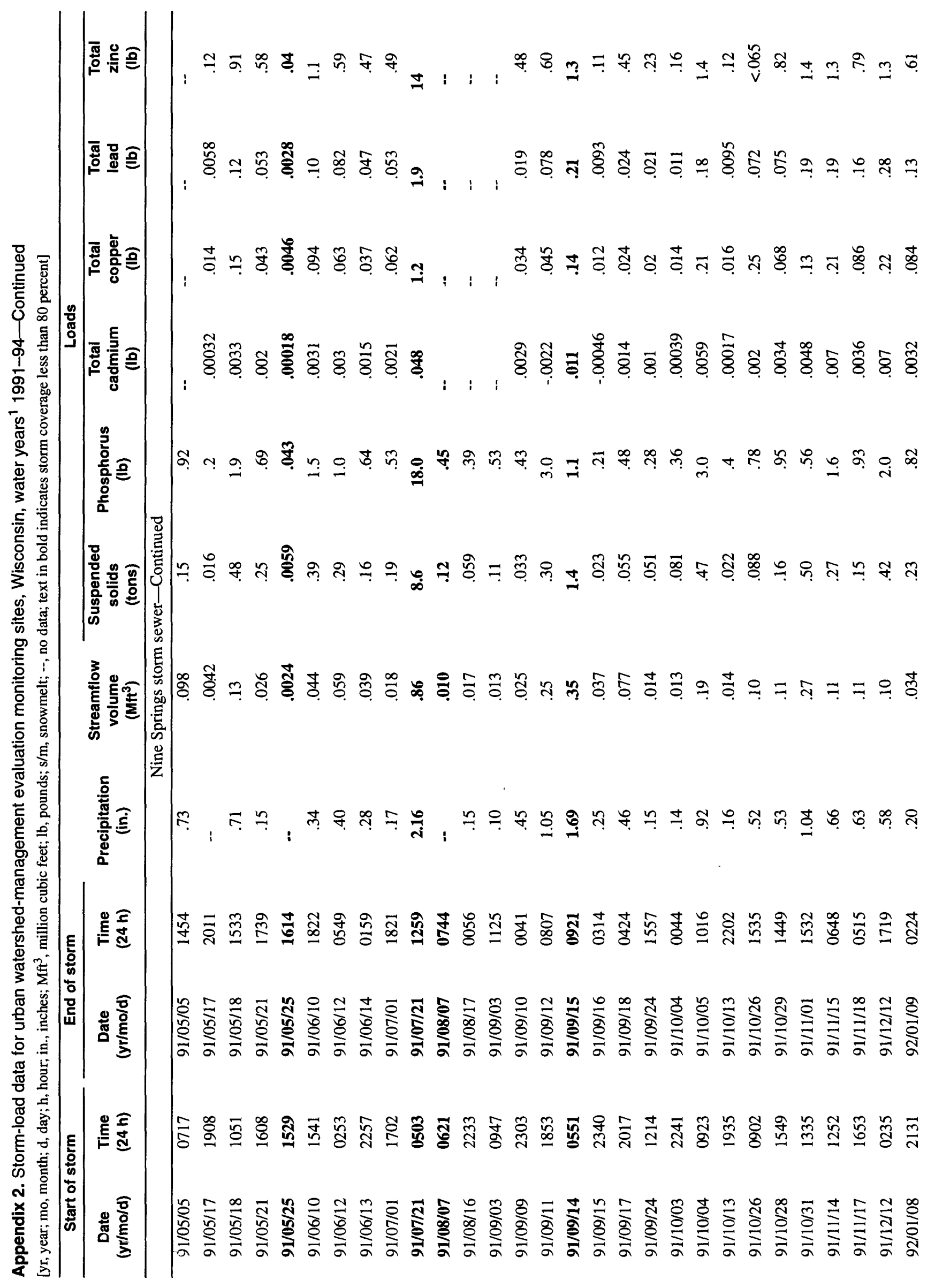




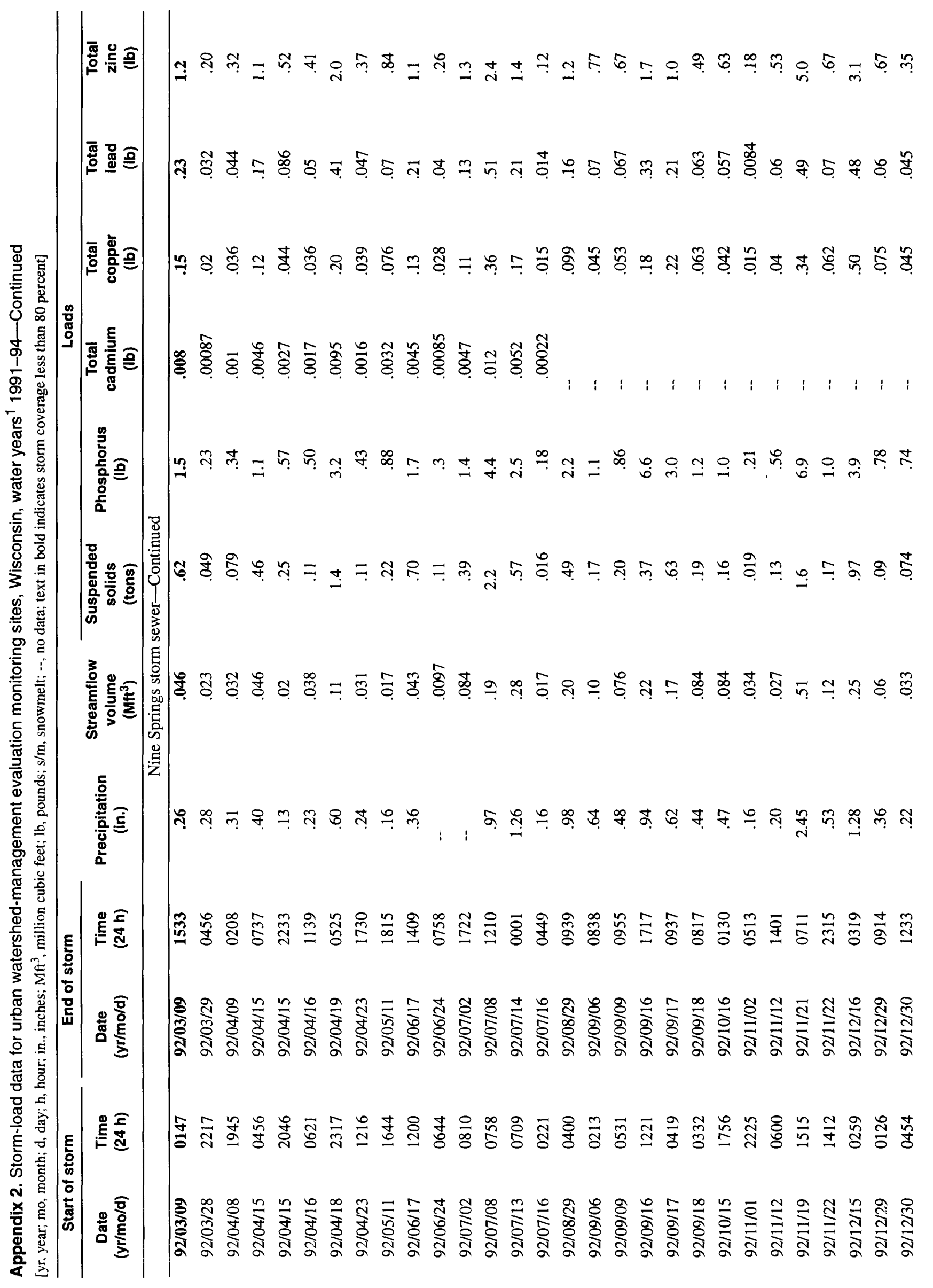




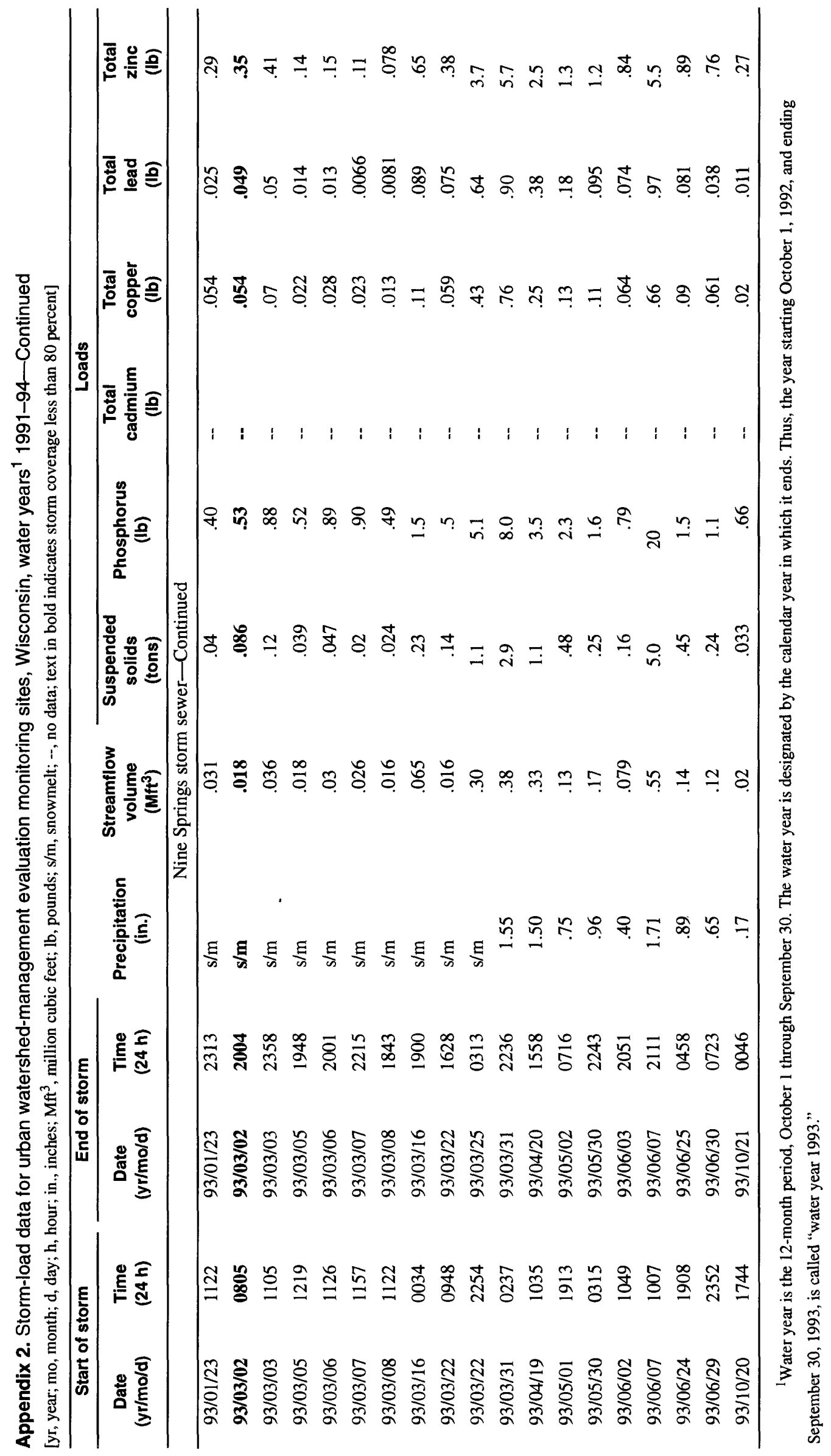




\section{Appendix 2.1 Uncertainty in Urban Storm-Load Data}

For each storm load listed in appendix 2, there is an associated uncertainty. Errors in measurement of discharge, sampling technique, sample processing and sample analysis all contribute to uncertainty in the final load. The following discussion addresses these errors and describes how their probable magnitude was used to estimate error in the final load.

The load is calculated as the product of event mean concentration and stormflow volume, so error in any particular load will include error from stormflow volume and error from event mean concentration. These errors are defined as follows:

$$
\begin{gathered}
\eta_{c}=\frac{\hat{C}}{C_{t}} \\
\text { and } \\
\eta_{S}=\frac{\hat{S}}{S_{t}},
\end{gathered}
$$

where $\eta_{C}$ is the error term for concentration, $\hat{C}$ is the estimated concentration, $C_{t}$ is the true concentration, $\eta_{S}$ is the error term for stormflow volume, $\hat{S}$ is the estimated stormflow volume, and $S_{t}$ is the true stormflow volume. It follows that the error of the load is defined as

$$
\eta_{L}=\eta_{C} \eta_{S}=\frac{\hat{C} \hat{S}}{C_{t} S_{t}}
$$

For the purpose of this study, and because $\eta_{C}$ and $\eta_{S}$ have a lower limit of zero, $\eta_{C}$ and $\eta_{S}$ are assumed to be distributed lognormally, hence, $\eta_{L}$ would also be lognormal. In general, the errors presented above have two components: a systematic component, termed bias, and a random component, termed precision. There was insufficient data collected to determine the bias of $\eta_{L}$; hence the errors were assumed to be unbiased. The precision was estimated as the variance of $\eta_{L}$, which is determined by adding the variances of $\eta_{C}$ and $\eta_{S}$ in $\log$ space.

The variance of $\eta_{S}$ must be estimated separately for each site. The 95 -percent confidence interval has been estimated by USGS personnel for error in discharge records (Holmstrom and others, 1993-95), and therefore for stormflow volume. For the lognormal distribution, the log-space standard deviation of the error in stormflow volume can be estimated by solving the following for $\beta_{\eta}$ :

$$
I_{95}=\exp \left(1.96 \beta_{\eta s}\right)-\exp \left(-1.96 \beta_{\eta s}\right)
$$

where $\beta_{\eta s}$ is the log-space standard deviation of $\eta_{S}$, and $I_{95}$ is the 95-percent confidence interval for the stormflow error.

The variance of $\eta_{C}$ must be estimated separately for each analyte. In determining the variance of $\eta_{C}$, sampleprocessing duplicates, field blank samples, laboratory blanks, and laboratory duplicates were considered. Data were insufficient to consider how well point samples collected during this study represent actual concentrations from the entire profile of the stream or storm sewer.

The variance of the error in concentration for each pair of sample-processing duplicates (Box and others, 1978) is

$$
V\left[\eta_{P D i}\right]=\frac{2\left(C_{1 i}-C_{2 i}\right)^{2}}{\left(C_{1 i}+C_{2 i}\right)^{2}},
$$


where $\mathrm{V}\left[\eta_{P D i}\right]$ is the variance of the error in the $i$ th pair of duplicates, $\mathrm{C}_{1 \mathrm{i}}$ and $\mathrm{C}_{2 \mathrm{i}}$ are the concentrations of the $i$ th pair of duplicates. The estimate of variance in concentration error from sample processing duplicates, V[ $\left.\eta_{P D}\right]$, is the average of the variance of all pairs of duplicates (Box and others, 1978) or

where $\mathbf{n}$ is the number of duplicate pairs.

$$
V\left[\eta_{P D}\right]=1 / n \sum_{i=1}^{n} \frac{2\left(C_{1 i}-C_{2 i}\right)^{2}}{\left(C_{1 i}+C_{2 i}\right)^{2}},
$$

The variance for the constituents in field blank samples was calculated directly from constituent concentrations in the field blanks. Variance of laboratory blanks were obtained directly from the Wisconsin State Laboratory of Hygiene (WSLH). The laboratory duplicate tolerance, obtained from the WSLH, was considered to be a 99percent confidence interval. As with stormflow volume, the log-space standard deviation of the error in laboratory duplicates $\eta_{L D}$ can be estimated by solving the following for $\beta_{\eta L D}$ :

$$
I_{99}=\exp \left(2.58 \beta_{\eta L D}\right)-\exp \left(-2.58 \beta_{\eta L D}\right)
$$

where $\beta_{\eta L D}$ is the log-space standard deviation of $\eta_{L D}$ and $I_{99}$ is the 99 percent confidence interval for the laboratory duplicate tolerance.

Because sample-processing duplicates include all sample-processing and laboratory procedures, variance in sample-processing duplicates should include variance inherent in field blanks, laboratory duplicates, and laboratory blanks; therefore, variance in sample processing duplicates should be greater than or equal to variance from field blanks, laboratory duplicates, and laboratory blanks. This was true for suspended solids, total phosphorus, cadmium, copper, and lead; however variance in laboratory duplicates was greater than variance from sample processing duplicates for zinc. Consequently, variance in sample-processing duplicates was used to estimate variance in error of concentration for all analytes except zinc, for which variance in laboratory duplicates was used. Final real space standard deviations are shown in table 1.

Table 1. Standard deviation of error for constituents used to estimate storm-load data from urban watershed-management evaluation monitoring sites, Wisconsin, water years 1991-95 [standard deviation (s.d.) in percent of true concentration]

\begin{tabular}{lcll}
\hline \multicolumn{1}{c}{ Constituent } & s.d. & Constituent & s.d. \\
\hline Suspended solids & 12 & Total copper & 7.1 \\
Total phosphorus & 6.8 & Total lead & 7.8 \\
Total cadmium & 17 & Total zinc & 3.9 \\
\hline
\end{tabular}

The variance of the load of each analyte, $V\left[\eta_{L}\right]$, was determined by transforming $V\left[\eta_{C}\right]$ and $V\left[\eta_{S}\right]$ to log space and summing the two. $\mathrm{V}\left[\eta_{\mathrm{C}}\right]$ and $\mathrm{V}\left[\eta_{\mathrm{S}}\right]$ are transformed to log space using the following equation:

$$
\beta^{2}=\ln \left(1+\frac{\sigma^{2}}{\mu^{2}}\right)
$$

where $\beta^{2}$ is the variance in $\log$-space, $\sigma^{2}$ is the variance in real space, and $\mu$ is the mean in real space. $\mu$ was calculated by trial and error assuming the mean in log space to be 0 (unbiased errors) and using the equation:

$$
\mu^{4}=\left(\sigma^{2}+\mu^{2}\right)
$$


The upper and lower limits of the 95-percent confidence interval in log space are $1.96 \beta$ and $-1.96 \beta$, expressed as a fraction of the true load. To transform back to real space and determine the 95 -percent confidence limits of the estimated loads, the following equations were used:

$$
\begin{aligned}
& L_{+95}=\exp \left(1.96 \beta_{\eta L}\right)-1 \\
& \text { and } \\
& L_{-95}=\exp \left(-1.96 \beta_{\eta L}\right)-1
\end{aligned}
$$

where $\beta_{\eta L}$ is the $\log$ space standard deviation of $\eta_{L}$, and $L_{+95}$ and $L_{-95}$ are the upper and lower limits of the 95percent confidence intervals of the estimated loads in appendix 2 . The values of $\mathrm{L}_{-95}$ and $\mathrm{L}_{+}$, , expressed as a percentage of the estimated load for each analyte at each urban site, are given in table 2 .

Table 2. Ninety-five percent confidence limits for storm-load data from urban watershed-management evaluation monitoring sites, Wisconsin, water years 1991-95

[values in percent of estimated load]

\begin{tabular}{lcccccccc}
\hline \multirow{2}{*}{ Constituent } & \multicolumn{2}{c}{ Lincoln Creek } & \multicolumn{2}{c}{ Menomonee River } & \multicolumn{2}{c}{$\begin{array}{c}\text { Monroe Street } \\
\text { detention pond }\end{array}$} & \multicolumn{2}{c}{$\begin{array}{c}\text { Nine Springs tributary } \\
\text { storm sewer }\end{array}$} \\
\cline { 2 - 9 } & Lower & Upper & Lower & Upper & Lower & Upper & Lower & Upper \\
\hline Suspended solids & -24 & 31 & -22 & 28 & -26 & 35 & -22 & 28 \\
Total phosphorus & -18 & 22 & -15 & 18 & -21 & 27 & -15 & 18 \\
Total cadmium & -19 & 23 & -16 & 19 & -22 & 28 & -16 & 19 \\
Total copper & -31 & 44 & -30 & 42 & -32 & 47 & -30 & 42 \\
Total lead & -19 & 24 & -17 & 20 & -22 & 28 & -17 & 20 \\
Total zinc & -16 & 19 & -12 & 14 & -19 & 24 & -12 & 14 \\
\hline
\end{tabular}



